\title{
The Job of Thinking People: Dialogues with Sefita Hao'uli, Kalafi Moala, and Melino Maka
}

\begin{abstract}
Howard Zinn wrote "it is the job of thinking people not to be on the side of the executioners" (Zinn, 2003). Democracy by Zinn's view operates beyond state nationalism and a capitalist economy. Represented in people movements, it is the grassroots activism, protests, and boycotts of the people from below that gives democracy meaning. This third essay of four prompted by dialogues with Sefita Hao'uli, Kalafi Moala, and Melino Maka explores the political climate in which people movements are transmitted and spread in present day Tonga. If it is "the job of thinking people not to be on the side of the executioners" then which side is the executioner? (Zinn, 2010). Considering the Nuku'alofa riot of November 16th 2006 muddied pro-democracy believability, how have people movements regrouped and recovered? Social activism in this age of political reform conveys what exactly about development? And how do people movements influence Tongan critics, the thinking people, to write social criticism and political commentary?
\end{abstract}

\section{Afakasi is redundant \\ you said \\ your evolution in terminology}

Teena Brown Pulu has a PhD in anthropology from the University of Waikato. She is a senior lecturer in Pacific development at AUT University. Her first book was published in 2011, Shoot the Messenger: The report on the Nuku'alofa reconstruction project and why the Government of Tonga dumped it. 
discrediting my whole history of identity

all I've ever known is this

holding on to this term

with a tight fist

no more afakasi

must mean

I don't exist

But

Afakasi is my generation

a product of your migrations

she feels

that is how I know she is real

she can't be dead

she lives in me, you, half the generation

in my neighbourhood

She breathes

she changes

chameleon-like

she's not dead

she evolves

into representations of

stories

struggles

hopes

dreams

Half caste

Smashing casts

moulds constructed by others 


\author{
casting shadows \\ on taboo territories \\ you can't talk about that realities \\ cast out \\ out cast \\ thinks \\ moves fast \\ looks past
}

\title{
Colour!
}

\section{Grace Taylor}

"All I've ever known is this. Holding on to this term with a tight fist," exclaimed Samoan/English poet Grace Taylor from South Auckland (Taylor, 2013a, 2013b). Drawing attention to the half-cast label and people who wear it willingly, Taylor explained that the name half-cast is what they know as their cultural truth, their lived reality. She was pointing out folks like me, the author of this Tongan tale about "the job of thinking people" (Zinn, 2003).

After drafting the bulk of this essay, I checked in with Sefita Hao'uli to see if he thought I was on the right track or had veered off to a side-road, one that existed in my own social imagination of being half not full Tongan (Mills, 2000). Sifting through Sefita's questions, his probing into corners that consciously and unconsciously were out of my view, I went back and read what I etched in black print on white pages. Wittingly I carved out my own story. In doing so there were blind spots and gaping silences I had not seen nor spoken to; obscurations which were perceptible to Sefita but escaped my sight. 


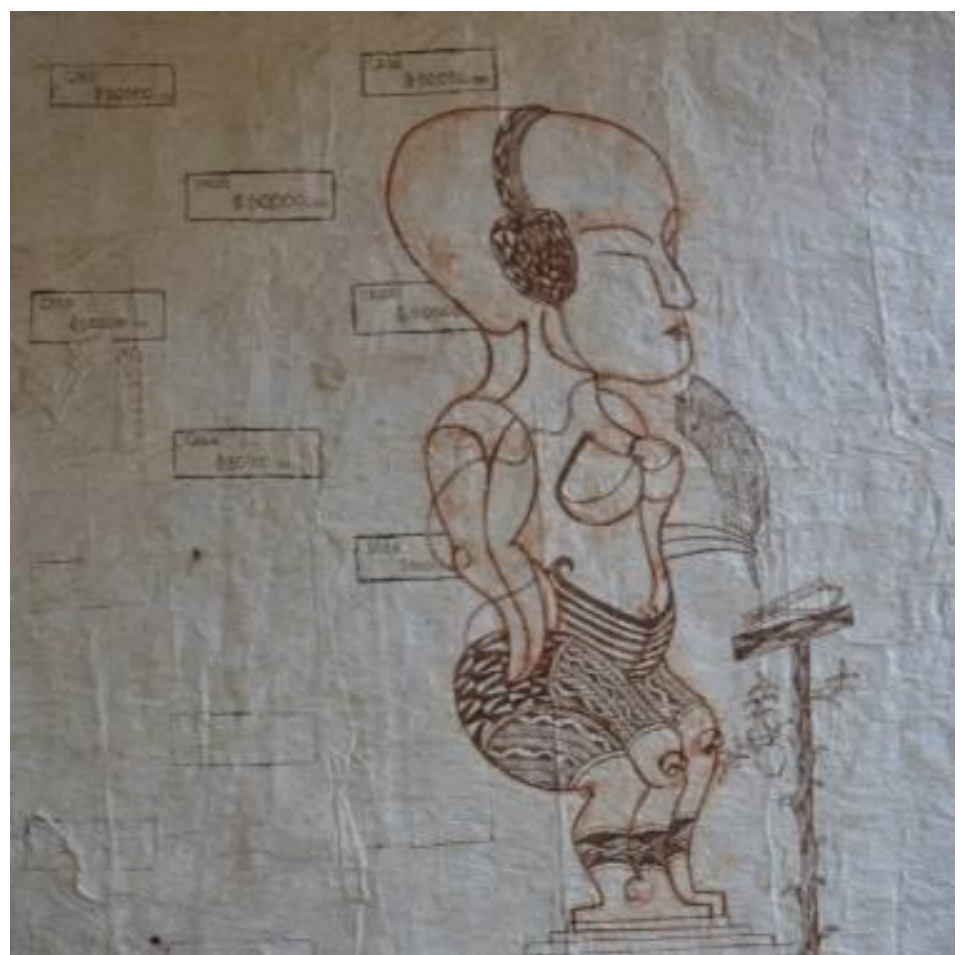

A design in progress that was transferred to ngatu (bark cloth) by Tongan artist Visesio Siasau of Ha'apai and Haveluloto in the Kingdom of Tonga. The figure depicts conflicting Tongan and Western values. An ancient god writing with a quill at a church podium; the god is adorned in traditional body art and head phones with church donation cheques for $\$ 80,000$ cash in the background. Photograph by Serene Tay.

I could say that identity tension for me operating inside Tongan networks, whether that be as an academic and writer, or as a daughter of Tonga frequently visiting my maternal homestead in Haveluloto to work on community development projects, cultivated a different set of experiences to Sefita and 
the older generation to whom he affiliated (Taylor, 2005; Kelly et al, 2005).

He was part of the earliest group of professionals born and raised in the homeland state who were university educated overseas in the 1960s. This group identified singly as Tongan. I did not, and here lay our point of departure. The obvious difference aside, my query was how divergent and distant did we stand on analysing the culture of everyday life? Were we so alien and unfathomable to each other no mutual priorities or principles were transacted when we discussed development in Tonga?

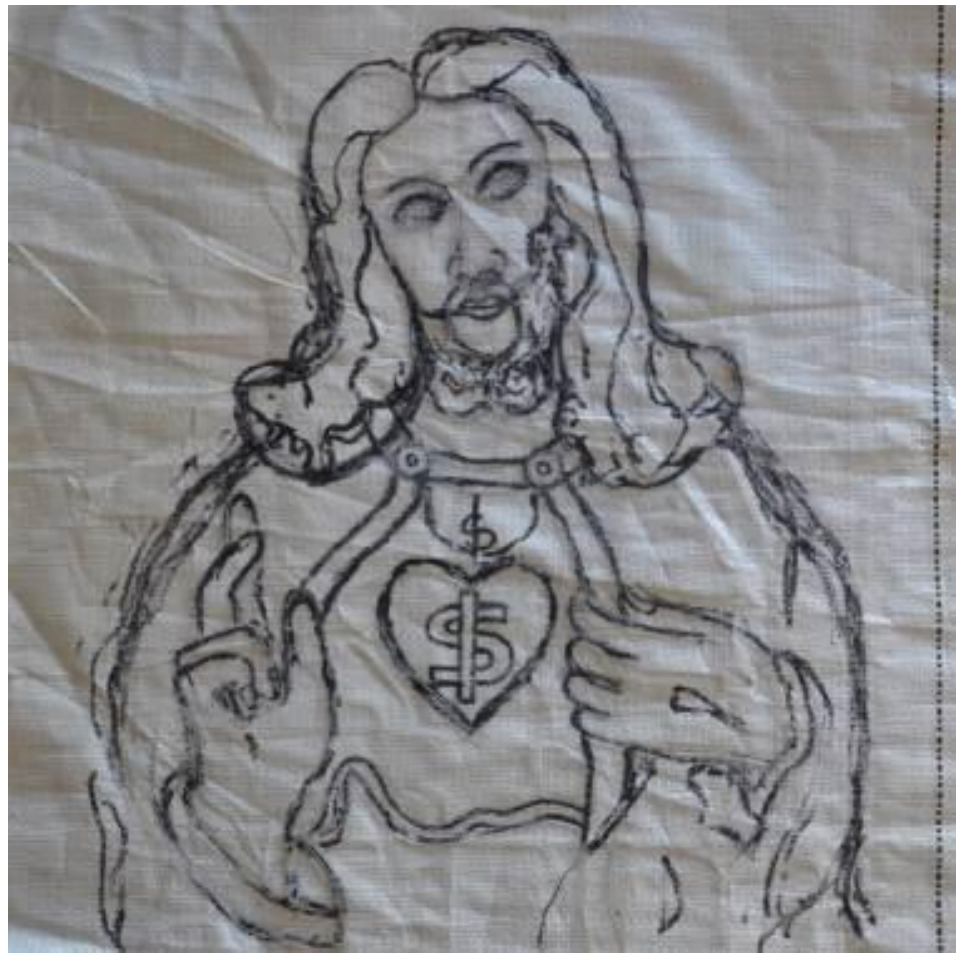

A design in progress on a piece of sacking that was transferred to ngatu (bark cloth) by Tongan artist Visesio Siasau of Ha'apai and Haveluloto in the Kingdom of 


\section{Tonga. The figure depicts a Catholic portrait of Jesus with a dollar sign imprinted on the 'sacred heart.' Photograph by Serene Tay.}

I was not entirely exempt from the structural constraints of conservative culture at all. But what I did have was a border crosser's pass I acquired for pushing my half-cast, English as a first language, born overseas status. In some situations (not all), it created openings to manoever around compliance with standard protocols of Tongan speech, thought, behaviour, church membership, and dress such as wearing a ta'ovala or kiekie to visit the government offices of cabinet ministers and senior bureaucrats.

To reword Grace Taylor, I held "on to this term with a tight fist," and not just because it was "all I've ever known" (Taylor, 2013a, 2013b). More importantly, half-cast validated my stepping across the social restraints and mind controls enforced on Tongans like Sefita, the full-blooded kind who were born in Tonga. The system inside Tonga had stern limits to critical speech, thought, and writing, accompanied by pitiless punishments that were liberally dished out to rule breakers (Boyer, 2003; McDonald, 2009). I was a rule breaker of a specific identity type with a carefully planned exit route off the island and back to Auckland if ever the political climate got unbearable.

Framing identity politics to reveal another view, my "willto-truth" as Foucault put it, which is my tenacity to argue for Tongans of mixed-blood who are mindful to avoid replicating, imposing, or falling prey to class structure, put me in a quandary (Foucault, 1980b). In my bloody-mindedness to expose intolerance and discrimination executed against my kind, the mixed-blood Tongan navigating a complex maze of not fitting in one culture or another but having ties to various peoples and locations at the same time, I paid little attention 
to conflicts that people classifying themselves as solely Tongan go through. Theirs was the established, stable, secure position central to being Tongan, I surmised.

Electing to speak from a place of half not full, insider and outsider, partly accepted though readily despised, I figured my lot was hard-pressed on the edge, shunted to the margin, and beyond the Tongan range of tolerability. As a result of my unabashed self-promotion, I somewhat missed the mark. I know that now after Sefita's conversation stimulated me to visualise clearly with both eyes open, not one eye shut.

My "will-to-truth" put up blinkers, constricting my peripheral vision to refocus on me because "holding on to this term" half-cast even though it was highly unstable, contested, and constantly in flux is "all I've ever known," and all I ever wanted from my own people was social acceptance that I am different (Taylor, 2013; Foucault, 1972). I did not desire a national road map on metamorphosing into a real Tongan. I sought to be different without burdensome bullets getting fired from my easily offended critics testy about preserving pure bloodlines and fundamentalist tradition to ensure I stayed permanently on the outlawed list.

What I am saying is there are a number of full-blooded Tongans who want this too. Not to be recorded on the prohibited register, but to have tolerance, inclusion, and acceptance of their resistance to the status quo, their variance from social norms, and their dissimilarity with a hierarchical structure the majority of Tongans think is the momentous characteristic of ancient and modern Tonga.

Culture is not genetically frozen in human DNA and bloodlines. For the most part, it is a social system of institutions, rules, taboos, tastes, and sensitivities transmitted and practiced through learned behaviour. Furthermore, human agency can and does change culture, just as individuals possess the resolve to discontinue culture-driven 
practices such as regular church attendance if it is no longer relevant to, or compatible with, shifting lifestyles and values.

Sefita alerted me to "the strictures and structures that produce tensions" for Tongans like him; full-blooded Tongans performing multiple and often conflicting roles while appearing securely fastened inside the parameters of what is conventionally recognised as Tongan culture, language, and identity (Hao'uli, 2013). What I learned is that the identity marker of being singly Tongan was in fact volatile, shifting, and changeable.

Sefita Hao'uli: In Tonga, if you are a number of things; a thinker who looks over the horizon and signals what is coming, a media operator who asks the questions, and a devout Christian who maintains conservative traditions, then you are in trouble and in conflict. There are strictures and structures that produce tensions in Tongan society for those who have multiple roles, both modern and traditional, liberal and conservative. To put Malakai [Koloamatangi] in context, he is a university academic and a matapule [traditional orator] which are roles attributed with different functions and social expectations for different audiences.

Teena Brown Pulu: That's why I hold on to being halfcast. My clever mother gave me this identity and raised me how she was raised European in Tonga. She knew it was social, intellectual, and financial freedom from Tongan culture and the hierarchy, the structure. Mum always wanted me to be free and not have to do any of it. The half-cast label gets me out of trouble because I can say, "I am sorry. I am half-cast. I don't do your culture."

Sefita Hao'uli: It gets you into trouble too.

Teena Brown Pulu: Yes it does I can say things and write things that full-blooded Tongans can't. Culture holds them down. I don't think they can think and behave like me. I know 
I can't think and behave like them. One day Tongan academics are pushing democracy and rights for the people, and the next they're being nice about the king, the nobles, the church, upholding the hierarchy as subservient commoners. They don't explain themselves, why they change in midstream.

Sefita Hao'uli: What you have to articulate clearer in the essay are the competing tensions between multiple roles in Tongan society that produce conflict and positions which are not easily defensible, such as one day supporting democracy and the next supporting hierarchy. A question to raise is how situations emerge when the majority of Tongans who want to move away from hierarchical structures are in conflict, and replicate the same hierarchical strictures and structures they originally sought to change.

Sefita was right. If I have to start off by answering my essay question in a coconut shell - who were Tonga's thinking people? - then he was a main contender for the national title: A pun on hierarchy and the landed gentry of title-holders intended. This essay still centres me as the main political actor framing the questions, interpreting responses, and selecting sights and sites of social interchange which readers consume. Although I cannot deny I am a tad thrown offbalance knowing from Sefita's discussion that the full-blooded Tongan marker I had tested and contested to get some halfcast parity on the identity table can be unstable and complexly problematic for its full-blooded inheritors. This was not how I thought culture and identity was for them. How little I knew of the other.

Full-blooded Tongans had identity trouble (Medina, 2003). Their tensions showed similar undercurrents, strains, and stresses to my situation as the half-cast simply because Tongans were not a homogeneous population. Identity was not fixed in time and across generations because the culture it 
was glued to transforms, transmutes, and transfigures. Finally it made sense to me why the Tongan identity police patrolled the border for dissenters and boundary crossers to discipline and punish into good behaviour.

They were not after my arrest at all. The conformists were more worried about their own kind going AWOL, absent without leave, than what they were about the half-cast rebellion. I was well down the most wanted list for identity breaches. The difference was generally full-blooded Tongans elected not to publicise their trouble openly, vocally, and by the same direct manner of thinking and speaking that I chose to front-up to mine, which if anything, made a telling statement about how top-down power silences criticism and smothers dissent in a small island Kingdom (Sheriff, 2000).

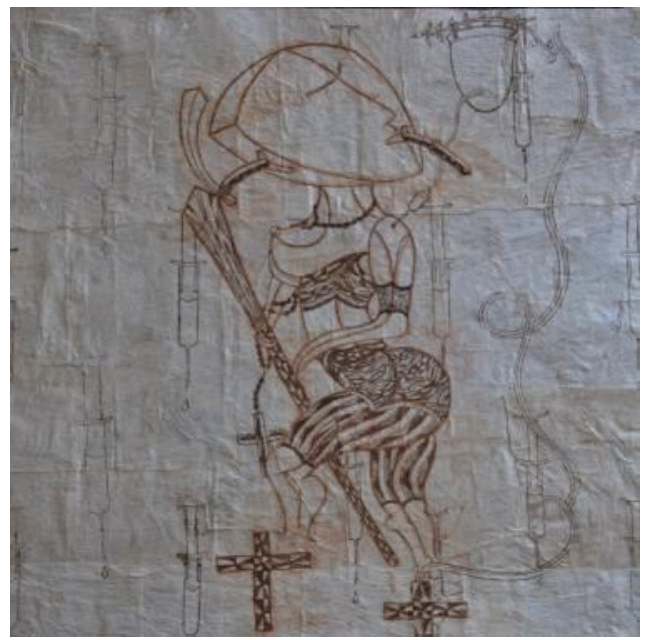

A design in progress that was transferred to ngatu (bark cloth) by Tongan artist Visesio Siasau of Ha'apai and Haveluloto in the Kingdom of Tonga. The figure depicts an ancient Tongan god with a war club playing a flute and standing on crucifixes. The god is connected to 


\section{a dialysis machine for kidney failure. Photograph by Serene Tay.}

Rethinking how Tongan nationalism creates an "imagined community" of people who assumedly, but in reality do not, ascribe to cultural symbols and practices of sameness, I leaned on Benedict Anderson's work. His book, Imagined Communities, explained how powerful as well as limiting the social imagination becomes in nation making and defining political sovereignty (Anderson, 1991; Mills, 2000; Brown Pulu, 2013).

[The nation] is an imagined community - and imagined as both inherently limited and sovereign. It is imagined because the members of even the smallest nation will never know most of their fellow-members, meet them, or even hear of them, yet in the minds of each lives the image of their communion. ...Finally, it is imagined as a community, because, regardless of the actual inequality and exploitation that may prevail in each, the nation is always conceived as a deep horizontal comradeship. (Anderson, 1991, pp. 5, 7).

Explicably, the idea of full-blooded Tongan is crucial to maintaining a conservative brand of nationalism deep-rooted in an "imagined community" (Anderson, 1991). There is no such thing in rational terms because every human being who identifies as Tongan or part-Tongan alike has traceable bloodlines to other than Tongan ancestors. However, it is the prevailing notion that compellingly limits human agency, restrains individual choice, and cordons off a sovereign territory of culture exclusive to Tongans who toe the line without question or defiance. 
In theory, a people who conform to an omnipotent logic of culture-centered nationalism appear less openly resistant to top-down manipulation and control. More than that, the unequal distribution of wealth and resources across classes of people is less important to maintaining the culture of nationalism that allows social inequality to flourish (Lemelle and Kelley, 1994; Hearn, 2006).

Uncovering resistance from below the hierarchy is my interest as an anthropologist and author who writes back to the centre from the periphery as a strategy for social action. Under what circumstances do people categorised as fullblooded Tongan transgress boundaries through conscious acts of questioning and challenging the status quo? By taking social action, is it plausible to argue that this signifies "the job of thinking people" in present day Tonga? (Zinn, 2003; Porta and Diani, 2006).

\section{Which side is the executioner?}

Nations are not communities and never have been. This history of any country, presented as the history of a family, conceals the fierce conflicts of interest (sometimes exploding, often repressed) between conquerors and conquered, masters and slaves, capitalists and workers, dominators and dominated in race and sex. And in such a world of conflict, a world of victims and executioners, it is the job of thinking people, as Albert Camus suggested, not to be on the side of the executioners.

\section{Howard Zinn}

In his book, A People's History of the United States: $1492-$ Present, Howard Zinn was sure about "the job of thinking 
people" (Zinn, 2003). Social critics and political commentators held a distinct position independent of the state. In a liberal democracy they were not, by any means, "to be on the side of the executioners" (Zinn, 2003). Howard Zinn is definitely not Tongan. If he was he would closely inspect the line between "thinking people" and the state that governs over them, and notice the boundary is hazy.

Tonga is the only independent Pacific Island state I have experienced where citizens with doctoral degrees behave as if working for government in a senior bureaucrat's role or getting elected to the legislature in a commoner parliamentarian's role are the supreme jobs the qualification is worth. A doctor of philosophy degree is a meal ticket granting a commoner rights of access to enter into state power. It has little to do with independent criticism that Zinn attributes to "thinking people." It would be fair enough to propose that after the death of Futa Helu in February 2010, the most prolific and well published critic of the Tongan state, Tonga had fallen on hard times for recruiting "thinking people" to the job of thinking independently. In the real world of dollars and financial stress, the role of the independent critic sold out to government for a regular job that paid mortgages and bills, and raised families.

This could also be said for me and my kind, the comfortably resourced university academic. As part of a collective of Tongan intellectuals in New Zealand, Australian, American, and Pacific Island universities and research institutions, we do not appear to be publishing significantly on the homeland state in its transitional quandary from an absolute monarchy to something else, where understanding that something else is the brainteaser to be solved. Other people, white people mostly, write about us and our people, our origin islands, and in the process of conceding the insider voice to outsiders who prominently speak over us and our 
kind, the research ground and influence we mutually share and have access to because we are Tongan by blood, diminishes in value.

I suspect that deep at work is the Tongan psyche suggesting that once a PhD and a university job is acquired you have made it to the top, elevated the family status, and can collect salary and go. Made it to the top of what dung pile I do not know, as the guiding rule propelling the university industry is that academics must publish or perish. Put simply, if there are no steady publication outputs then there is no promotion to the throne as the right royal ruler of the dung pile, which could decompose and dry up under one's bottom if you are not constantly producing work in print. Of course I am being facetious here, but there is some cultural truth in what I am getting at. The economic recession has ensured that universities and research institutions are unsettled workplaces exposed to government funding cutbacks, redundancies, and job restructuring. No employee's position is fool-proof, sure-fire, and safe.

In saying that, what do Tongan academics contribute to development in the homeland state? Are they really "thinking people" by Zinn's allusion to independent thinkers, critics, and commentators? (Zinn, 2003). I could counter argue the purpose of Tongan academia is to extend the exclusivity of having institutional power over the general public to control the production and consumption of knowledge (Baudrillard, 1998). Tongans with doctoral degrees are largely dependent on government jobs and research grants to make a living. There is state dependency on salaries and funds, and in return the academic employee is expected to expand the university's brand, not singly to influence the decision-making of governments and societies, but to attract research investors and benefactors for the university's work. 
My probing is around what they actually do for the people. What is this elite group's function in society? If their role is not defined by the people from below then how are they answerable for the research and publications they produce? Ordinary Tongan people do not read publications by their own PhDs because the body of literature is written in English not Tongan; nor do they have easy access to getting copies to read. Likewise, do Tongan academics employed by universities carefully read people movements in Tonga? Do they publicly comment with integrity and social responsibility by using scrupulous methods that make sense of stressors and strains between the Tongan state and citizens?

As a university academic of mixed-up Tongan, European, Samoan, Maori blood I cannot answer with an "unequivocal yes," to paraphrase Dr 'Ana Taufe'ulungaki, a former academic of the University of the South Pacific and Tonga's Minister for Education (Television Tonga News, 2013a). And that is quite troubling for me and my dung pile which I have purposely built on Tonga's development. What Tonga was actually developing into has proven to be an enigma. Here was my ancestral homeland of fertile soils and cyclones; a growing population with high fertility rates; a people renowned for having fertile imaginations; a hierarchical system infested with fertile tensions; a parliament and government deadlocked in fertile disputes; which combined, produced a fertile mix that often exposed its potential to cultivate high-grade manure.

For Tongan academia appearing in the English-speaking media, Dr Malakai Koloamatangi, an older generation migrant Tongan male employed at Massey University Albany in Auckland has been handpicked by Radio Australia as the Tonga specialist. Often I have pondered whether his narrations are tailored for white people's interests by spinning tales that confirm outsiders' suspicions about us (Lee, 1998). His latest story painted a socially backward and antiquated 
island kingdom fanatical about royal marriages and blue blood.

There's an expectation that royal family members will marry other people of similar status because of the need to maintain the succession to the throne and there's this idea that you are the key blood undiluted as much as possible and for the maintenance of the monarchy. That's why it's important of course, the constitution had a particular way of putting it, that the marriages of the royal family are under the reigning monarchs prerogative and the monarch can annul the marriages of the royal family. The fourth [king] particularly did this to his reign. (Malakai Koloamatangi cited in Hill, 2013).

Commenting about two granddaughters of the late King Tupou Taufa'ahau IV who chose to marry commoners, Koloamatangi's impression of Tonga in 2013 backslid to a former time, century, and reigning monarch. Reading the past in the present, he presented a belief-driven opinion. By this, the interpretation was not grounded in recent research and publications on the people he is thought to represent in his voice, views, and vocalisation on Tonga. 


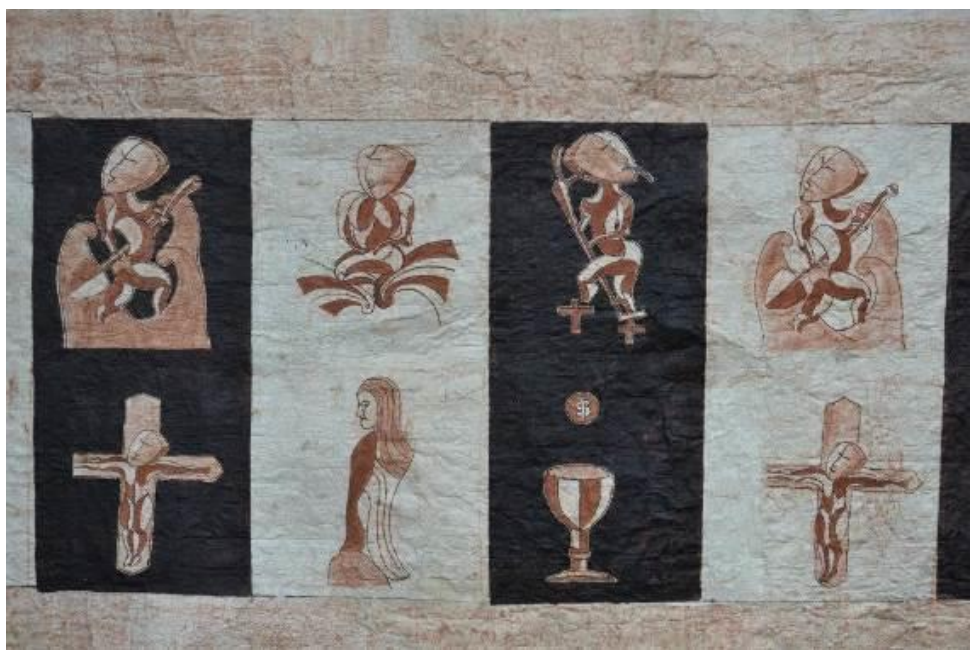

Ngatu (bark cloth) with hand painted figures representing ancient pre-Christian gods alongside symbols of Catholicism by Tongan artist Visesio Siasau of Ha'apai and Haveluloto in the Kingdom of Tonga. Photograph by Serene Tay.

Why would listeners not question an Aucklander's depiction of Tonga? The short answer is that because Koloamatangi features on Australian national radio, a social expectation prevails that he was chosen as the reliable judge of Tonga's development dilemmas. Whether he is or not does not figure. There are no other Tongan academics getting on Radio Australia and Radio New Zealand to contest the one voice which reflects the politics and preferences of these national broadcasters. Obviously, his views coincide with theirs. What I am saying is the media does not reproduce objective and disinterested reporting, and neither do academics if the truth be told. Subjectivity and identity shape who the speaker or writer is and their relationship to the subject they are speaking or writing about. 
An understandable but duplicitous situation emerges that Tongan academics interviewed by media on politics and society in the homeland state too readily stumble into. I say understandable because most, like Koloamatangi, live in developed countries and earn middle-class salaries. Their opinions veer towards outdated narratives of culture frozen in the 20th century, which echoes a past monarchy and conventions fixed in time. No longer living in the homeland nor enduring through the day-to-day gruel of limited job openings, hiked electricity, water and fuel prices, increased crime, multiplied cyclones and natural disasters, and land scarcity on the main island where 70 per cent of the country's youthful population reside, Tongan academics do not speak of lived reality but transmit social memory of what they think Tonga is like. Chancy and socially irresponsible reporting from the national broadcasters, Radio Australia and Radio New Zealand, the manner in which Tongan observers are singled-out to repeat a dominant view that Tonga is backward does little, if anything, to unshackle people movements from below.

Wordplay and prodding aside, a barbed point discomforted me personally as a hybrid-Tongan woman, and professionally as an anthropologist, academic, and author. Karen O'Brien discussed my unease. She explained that "a scientific approach" to producing "academic knowledge" through "writing" was invented by notions of objectivity and disinterestedness (O’Brien, 2008, p. 56). In this sense, writers distance the "self" (themselves) from the "subject" of study, giving readers the impression that they are separate, detached, and disconnected from the thing, the people, and the place being observed and recorded (O'Brien, 2008, p. 56).

In academic knowledge production there is a "scientific" approach in which an observer assumes a 
distance and separation between self and subject. This position is influenced by and is derived from the invention of writing. The scientific language which prescribes, distances and separates is the language of the university. (O'Brien, 2008, p. 56).

"The language of the university" which O'Brien calls attention to "is not impartial" and unbiased; nor is it independent (O'Brien, 2008, p. 56). It is in fact a discourse by Foucault's interpretation in that language, particularly exclusive language that is deeply coded and only within reach to an elite few, is purposely wielded to preserve an institutional system of power and knowledge allowing those who are privy to the language, the discourse, to create knowledge over and about those who are not (Foucault, 1972). Put simply, the elite few who produce "academic knowledge" through "a scientific approach" to "writing" are in a position of power to write about, write over, and write off those without that very power, which is clearly the majority of people in any given society (O’Brien, 2008, p. 56).

Writing, however, is not impartial; it is deeply imbued with meaning which creates opportunities for powerful groups to ensure that the unequal power relationship will be maintained through the use of academic language, writing and print. It is through these channels that the wielding of political power and social distancing will carry on. (O'Brien, 2008, p. 56). 


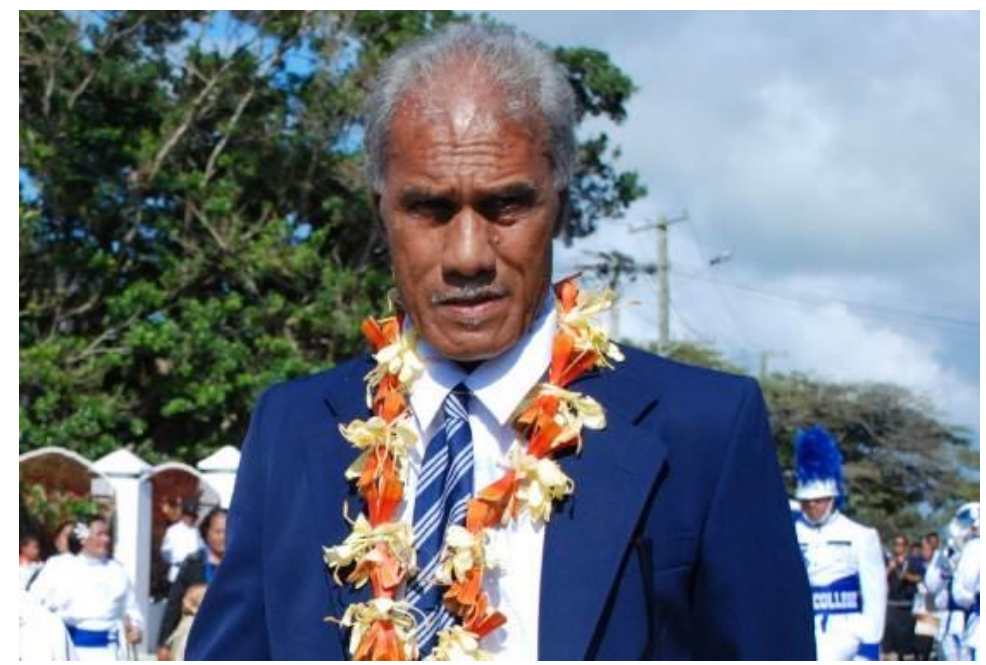

Leader of the Democratic Party of the Friendly Islands, 'Akilisi Pohiva, at the closing of parliament ceremony in 2010.

For Pacific Islander academics, O'Brien's critique that "academic language, writing and print" reproduces an "unequal power relationship" between the writer and the "subject," the mediator and the masses, is not intended as a cultural excuse not to learn the language of the dominant power at work in academia (O'Brien, 2008, p. 56). Quite the contrary. If anything, the social responsibility of Pacific Islander academics is to learn the institution's rules and canons of "language, writing and print" so to be fully armed and capable of challenging, transgressing and in the process, restructuring the very system that gives it power (O'Brien, 2008, p. 56).

My anxiety is how many actually do when considering the economic downturn propels Tongan academia in New Zealand, Australia and the USA to behave similarly to government bureaucrats and parliamentarians in the homeland state. 
Under present political conditions they are grateful to be employed, and the motivation driving them to work in universities and research institutes is middle-class income tied to social status, which adds value to their family standing and rank among Tongans.

As a collective employed in universities and research institutes of New Zealand, Australia and the USA, Tongan academics are not the "thinking people" of Zinn's social imagination. But as gatekeepers of power in an established institution, they guard their small individual territories as if they were 3.3 hectare plots of farm land allocated to eldest sons in the Tonga Land Act 1988. Protecting the patch is indicative of believing one has earned the right to a piece of intellectual turf (whether it had value on the scholarly market or not) for labouring to get a doctoral degree. In reality, academics are commoners with no rights to traditional leadership. However, the social deficit is mitigated by the fact that a commoner with a doctoral degree employed as a university academic has power and status exclusive to "academic language, writing and print" which the majority of Tongans, especially the monarchy and nobility, do not possess (O’Brien, 2008, p. 56).

It is this cultural fusion (or should I say confusion) which leads me to think that many Tongan academics are drawn to the power invested in having an honorific title, Dr So-and-so with a $\mathrm{PhD}$ from whatever university, because they cannot acquire the traditional kind; that is, the inherited male birth right of a noble's title and landed estate. A Tongan psyche embedded in the structural constraints of a small, class-based society is deep at work in the conscious and sub-conscious methods by which people make sense of, and accredit value to, social rank and hierarchy. The traditional scale of social importance persists as the authentic measure under which status is judged. What I am suggesting is that Tongan 
academics with $\mathrm{PhDs}$ are not altering social stratification but instead, assessing their status against the upper class of traditional title holders - the landed gentry - and gesturing that they occupy a significant role and place in society too.

Consequently, it is understandable that Tongans in the university system can become infatuated with getting formal titles and letters after their names for the wrong reasons. Crudely, the desire for authority and prominence in one's family and community hierarchy is the motivator. The prevalent mind-set is coveting to be well-known and of consequence to other Tongans, a commoner of influence who is given respect and attention. Contrary to mobilising Tongan academia as a cooperative driver for change, this attitude is highly individualistic and self-interested. Furthermore, it fails to appreciate the doctoral degree is a skills-set to grow and adapt to various situations.

Demystifying the qualification to reveal what it plainly is in a nutshell, a $\mathrm{PhD}$ is a knowledge-base, a disciplinary field of inquiry which can be used to make sense of problems, ask questions, gather information, craft solutions, and create improvement in the livelihoods and everyday lives of the people and places being studied. It does requires a high level of literacy and proficiency in critical thinking and analytical writing. But it is not the Nobel Peace Prize. The degree holder does not possess super human power and cannot perform miracles. It is conferment of a qualification printed on paper with a university seal.

An unrealistic way of thinking had taken hold where it can be said that Tongans attribute a doctor of philosophy degree with greater prestige and weight than what it actually has. To speak in a matter-of-fact tone, if the degree holder cannot convert the paper into practical work by applying a skills-set to improve real life situations, then its value is the paper it is 
printed on. And truthfully, those who have one are ordinary, everyday, run-of-the-mill people like the folks who do not.

Which brings me to the question, if our own academics as a collective are not sufficiently performing as social critics and political commentators of Tongan state and society, then who is doing "the job of thinking people?" (Zinn, 2003). Is it that the real thinking people are from within the people movements operating at the grassroots, village roots, and outer island roots? And what, precisely, represents the people movements of a post-2010 democratised Tonga?

Politically, a situation in Tonga ensued in that the prodemocracy movement leading up to the 2010 general election had lost momentum. Internal factions eventuated between elected parliamentarians of the 'Akilisi Pohiva led Democratic Party of the Friendly Islands, compounded by a decline in public popularity because party policies neglected to tackle unemployment and how to create jobs to put food on the table for the country's majority living below the poverty line. Pohiva's Democratic Party dropped the ball when it came to advocating for poverty elimination and addressing the population's basic needs of food, shelter, and clean drinking water.

The regional busybody was the New Zealand parliament who saw fit to meddle in Tongan politics by nominating Pohiva for the Parliamentarians for Global Action defender of democracy award 2013. Parading their parliamentary bias, New Zealand politicians wilfully demonstrated whom they wanted to head a democratised Tongan state (Lopeti, 2013). Could New Zealand not see beyond a 73 year old Tongan male as the only commoner for Tonga's top job? And why did their first preference have to be an older man? Why not a woman?

Political interference notwithstanding the future of the prodemocracy movement at the 2014 election looked uncertain given that the Democratic Party had internal splinter groups. 
My query is straightforward: What and where is Tonga's new substitute for social activism? Activism here means social action to gain equitable access to constitutional liberties and resources, such as education and employment, for vulnerable groups.

\section{People movements}

Never waste your time trying to explain who you are to people who are committed to misunderstanding you.

\section{Dream Hampton}

A neighbour of mine from Haveluloto, the village where my maternal grandparents' homestead is located on the urban fringe of Nuku'alofa, exhibited a collection of miniature glass and copper sculptures in 2012 at an Auckland art gallery. An artist for our contemporary times, Visesio Siasau's work merges figures of Tongan deities alongside religious symbols of Catholicism which he grew up with. Crucifixes, chalices, offerings of money, and statues of Jesus, Joseph, and the Virgin Mary feature prominently in his art. 


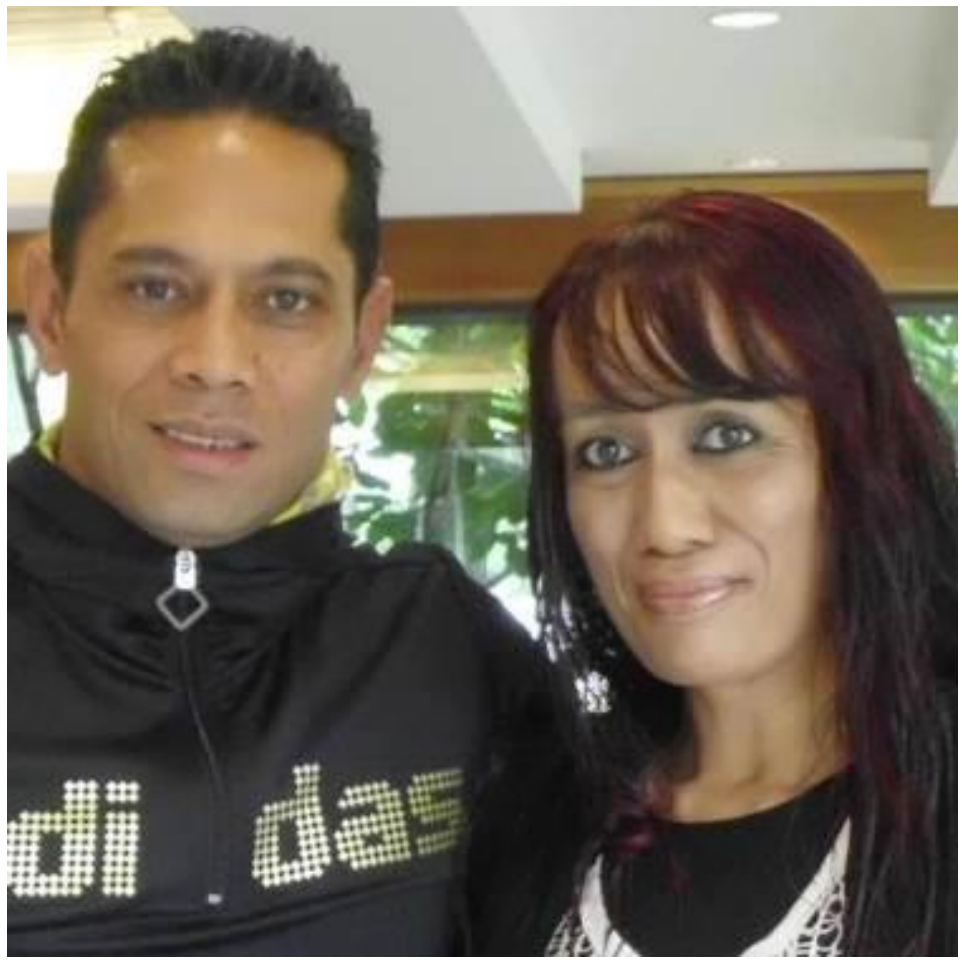

Tongan artist Visesio Siasau and the author, Teena Brown Pulu, at Auckland University of Technology's South Auckland campus in February 2013.

As the son of Catholic migrants to the main island from Ha'ano in Ha'apai, the atoll group north of Tongatapu, his sculptures are highly politicised. Consciously critiquing the power of the church in dominating and eradicating a pantheon of pre-Christian gods, he questions the displacement of indigenous histories and non-monetary economies. How does a Tongan past tainted and written over by missionaries, colonialism, modernity, and capitalism impact on its descendants in the present day? How do we make sense of 
disremembering the past and forced acts of purposely erasing historical memory and meaning?

Sio and I are from the same generation and age-group. We had been neighbours our entire lifetime, but true to class structure in Tongan society I first spoke to him as an adult in Hamilton, New Zealand where he had settled with his Maori partner Serene Tay who is also an artist and educator, and their children. From that time onward we were friends, neighbours from Haveluloto, and supporters of each other's work. But we had never talked in Tonga, and the fact that we did not exchange a word in the old country but could forge a close bond as village folk in New Zealand illuminated that migration involved more than physically shifting across geographical borders. Mass movement away from Tonga also collapsed class and race boundaries separating people, allowing them to mix and mingle in the new place, where in the old one it was self-consciously hard to manoever outside the social box.
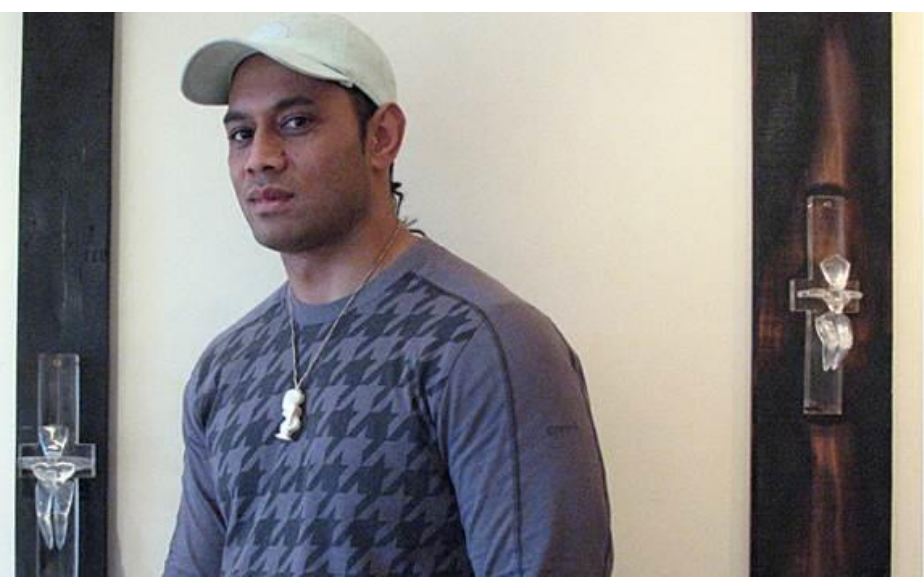

Miniature plastic statues of Tangaloa, god of the sea, nailed to the crucifix by Tongan artist Visesio Siasau of Ha'apai and Haveluloto in the Kingdom of Tonga. Photograph by Imogen Neale. 
At my university workplace in February 2013, Sio recounted his childhood impression of how he thought my family homestead was grand. He remembered feeling intimidated walking past our house on the way to church. Cautiously he would peer through the fence to catch a glimpse in the windows of who was inside this big Palangi (white/European) place. One time he caught sight of Auntie Nina, my mother's eldest sister in the kitchen, exclaiming to his friends "there's an old lady in there!"

A 1950s house assembled in New Zealand and planted in Haveluloto, in real life my family homestead was worn down from old age and three generations living in it. It might have been a big Palangi place in the 1960s when my half-cast mother and her siblings were schooling in Tonga and their neighbours mostly lived in Tongan-style dwellings. In 2013, however, it was an old-fashioned abode reminiscent of Tonga's colonial past when my British grandfather managed the Tonga copra board, taking his afternoon tea in thirty degree heat and wiping his brow with a pressed white handkerchief.

Sio's exchange opened up a place in social memory where we characterised each other's difference. Rather than thinking individually that this is the whole story about what the other is like, he arranged his thoughts on the talk table. I edited the script by adding my explanation of how I situated myself in his story. Reflecting back, I can see we were doing the crosscultural identity work of collective sense making. 


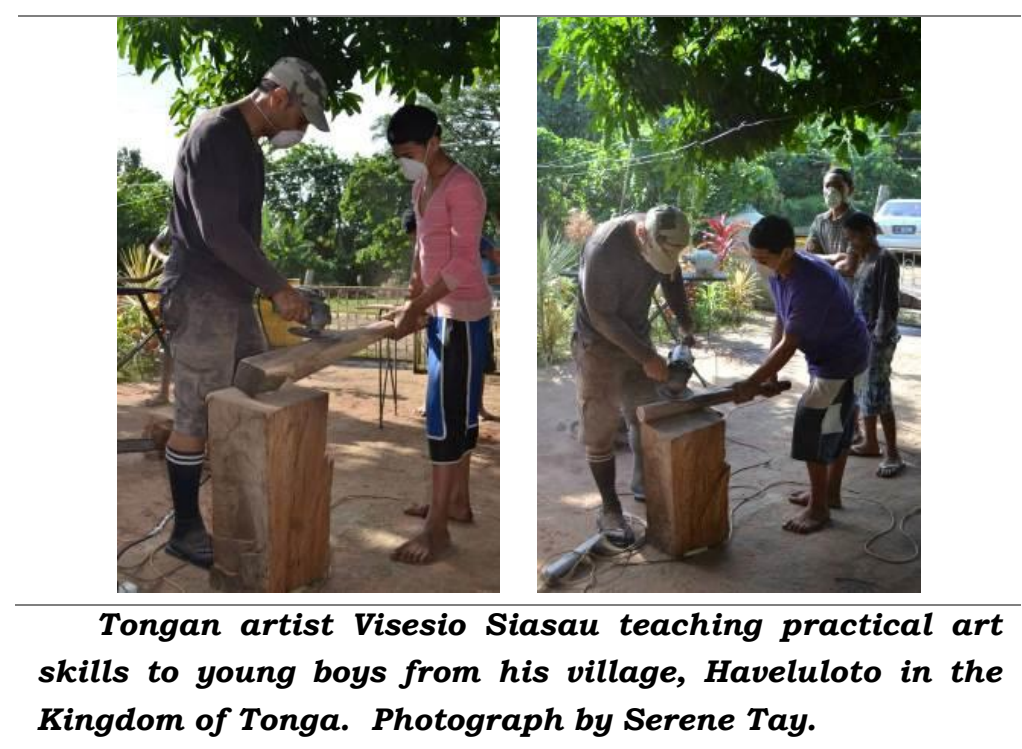

Visesio Siasau: Teena, it always amazes me that you can't talk Tongan, but you understand Tonga. You know what the people are saying about politics, the system, the leaders, the church, the culture, all of it. You know how the people think. But you were born here in New Zealand.

Teena Brown Pulu: It's because I'm half-cast. I watch and listen, but I don't have to be part of it. I'm on the outside. My half-cast mother did not send me to Havelu [Haveluloto village] every school holidays to learn about Tongan culture. No way. We're more European than Tongan. She just wanted me to be close to her sister Tina she named me after, stay in our homestead, remember her parents, so I'd feel connected there. I'm more connected to Tonga than New Zealand. Havelu is the only stable home I've ever known. When I go home, it's always the same way I left it. I've had more to do with Tonga than full- 
blooded Tongans born in New Zealand. There is something Tongan about me. It's my emotional attachment to Tonga.

Rewind to Sio's Auckland exhibition of miniature glass and copper sculptures in 2012, he recalled his work was well received in the visual arts community. Similar to academics and writers, public reputation is intricately tied to recognition from peers of the same specialisation (which in this case was sculpturing) that the work makes an original contribution to the artist's field. The obstacle was the artist's own community.

"The Tongans didn't like it," Sio confided. He was slammed for being political and making radical art involving pagan idols with genitalia and religious statues of Jesus, Joseph, and the Virgin Mary. Art should be aesthetically pleasing to Tongan senses and sensitivities, according to his critics. Troubling the touchy Tongan palate was Sio's questioning of belief systems. He prodded and poked the dogma of Christianity and the dislocation of pre-Christian history, arguing that Tongan ancestry is traced to a preChristian past which Christianity debunked. 


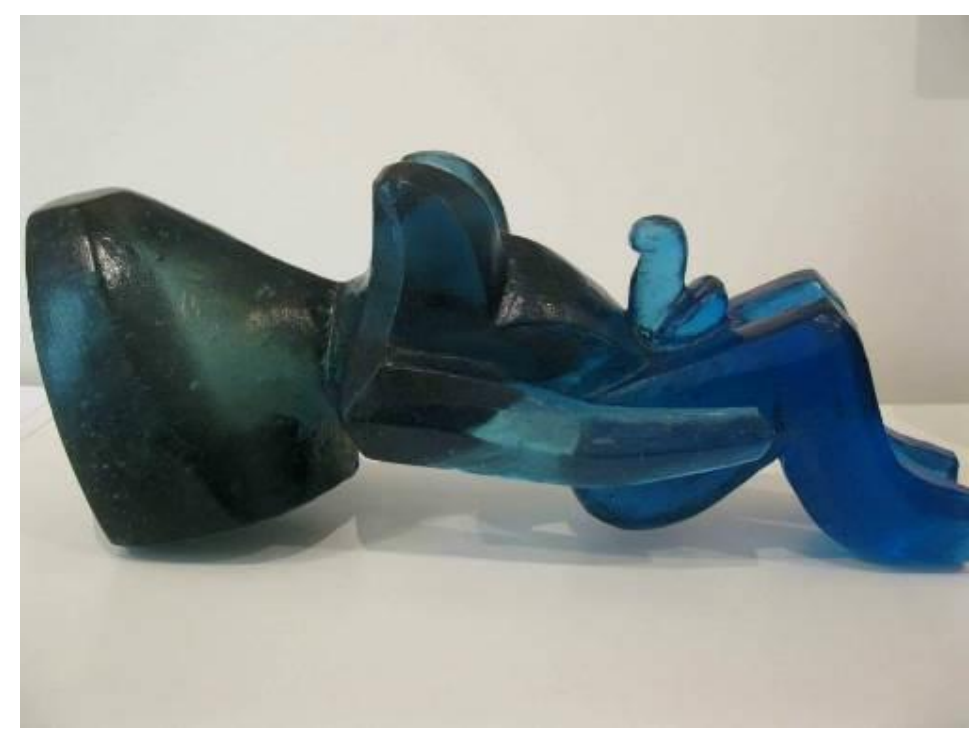

Meteaki, a glass sculpture by Tongan artist Visesio Siasau of Ha'apai and Haveluloto in the Kingdom of Tonga. Photograph by Serene Tay.

Sio relayed that his own father warned he would be cursed for going against the Roman Catholic Church. On this subject, we fell about laughing. Of course the rationale was not side-splittingly funny to an older Tongan generation indoctrinated by church canon. It expressed the characteristic reprimand for criticising religious conviction. As others have noted about Tonga, there are two cultural taboos which must be obeyed: Commoners cannot condemn the monarchy or the church. For doing so, a person would put themself at solemn risk of being ostracised and ousted from Tongan networks.

The Ahoeitu, translated as the dawn break, was Sio's first solo exhibition at Fresh Gallery in Otara, South Auckland during August of 2009. A feature article about his trademark miniature sculptures was written by Imogen Neale for New 
Zealand media. The headliner, Tiny statues - big statement was the attention grabber, drawing readers into the "complex conversations" which Sio's "statues represent" by visually depicting "the impact of contemporary life on traditional cultures" (Neale, 2009). Using an innovative material and method of sculpturing, "the statues in the Ahoeitu are crafted from blocks of Perspex and corian - a plastic commonly used in kitchen bench tops - using a band saw, an angle grinder, sanders and a hand dremel" (Neale, 2009). The figures characterised Tangaloa, the god of the sea nailed to a crucifix signifying "religion, consumerism and politics," which Sio remarked were "don't go areas" for Tongan and Pacific Islander artists (Neale, 2009).

But Sio purposely went there to the "don't go areas," the places prohibited to Tongan art and what was orthodoxly considered aesthetically pleasing (Neale, 2009). The visual imagery of plastic Tangaloa on the crucifix, in many ways, discomforted his own people's smugness and self-assuredness that "religion, consumerism and politics" were off-limits to artists who were not meant to be critics, social activists, and political commentators by Tongan ideals. Four years on from his 2009 solo debut he has sculpted his own identity - the political, controversial, outspoken Tongan artist - who pushes social boundaries, challenges class convention, and disrupts authority.

My story about Sio has a sharpened edge. His work is dedicated to transgressing cultural "no go areas" (Neale, 2009). Consciously, he cross-fertilised modern tradition - church, state, and a monetary economy - with apparitions of the past Tangaloa and indigenous deities. And he took this route to face up to what Tonga really is since the system of European colonial expansion expelled pre-Christian Tonga, replicating itself as the origin roots of a modern Tonga that we know, live, and experience. By breaking with today's Tongan norms of 
reasoning and behaviour, Sio tested the rules, contested authority, and retested the waters to see if he survived social exclusion among his own people. But the truly significant influence of his art practice was a skilful critique; simply because it showed greater commitment to "the job of thinking people" than the original inheritors of the role, Tongan academia (Zinn, 2003).

This urges me to ask, what is the job of media here? Is there a public expectation in Tonga that media has a social responsibility for fair and adequate reporting on people movements initiated by community activists? It comes as no surprise that Tongan media paid no attention to Visesio Siasau's art exhibitions of miniature statues. Governmentowned media dominates this small island developing state, and self-censorship controls "the order of things" by regulating the practice of day-to-day journalism (Foucault, 1970).

Why would local reporters publicise controversial artwork that Tongans might object to for visually unhinging their sensitivity about religion and pre-Christian idols? Selling the news is the industry's baseline activity for profit-making. Therefore, how would a journalist's employer benefit from publishing about Sio's art in light that it would not be a story comfortably fitted to Tongan popular tastes and interests? The broader media issue is public silencing around critiques of culture, which signals directly to the power differentials imbued in "the job of thinking people" (Zinn, 2003).

It was Edward Said who noted that his role as an academic and author is to speak truth to power because he is without power (Said, 2000). Echoed and evoked in Howard Zinn's (2003) argument that "thinking people" perform the duty of independent critics by having no political and financial strings attached to a government puppeteer, Said takes this one step further. The position of without power essentially grants him license to criticise, to think critically, and to write 
criticism of those with power. By this, he indicated that people at the hierarchy's top in positions of power define and confine knowledge over and about, as well as make decisions for, people from below without power (Said, 1978).

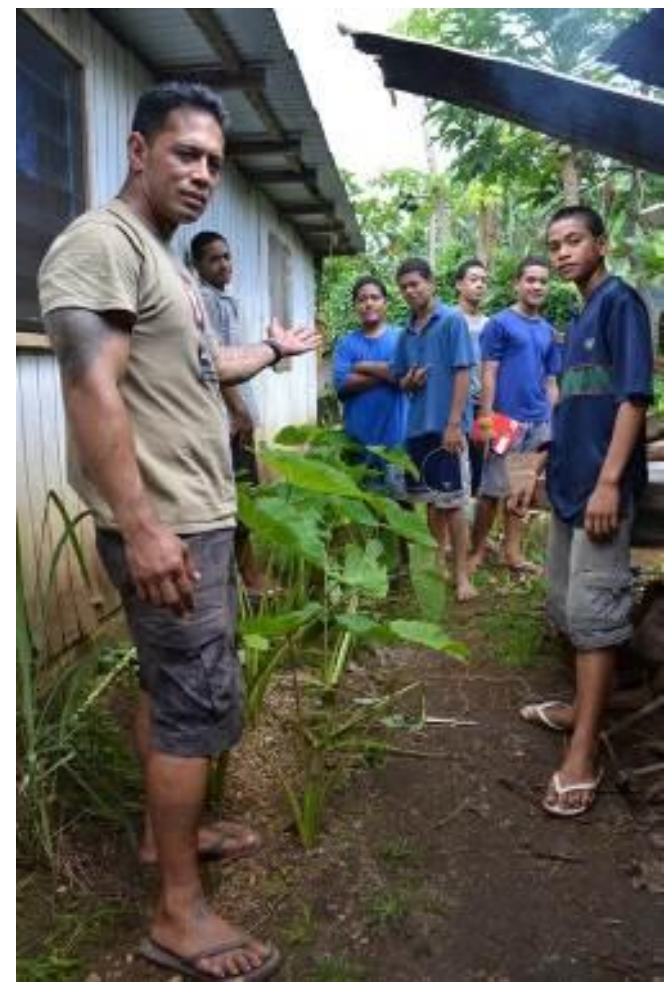

Tongan artist Visesio Siasau standing with a group of young boys from Haveluloto in the Kingdom of Tonga whom he mentors by teaching practical skills in carving and sculpturing. Photograph by Serene Tay.

As Michel Foucault explained, resistance is not separate from power, but in fact is a by-product of power (Foucault, 1980a). Power and resistance therefore operate in response to each other under a system, a structure, a political 
arrangement. The catch is the system of authority which an independent critic who is without power speaks back to and wants to change is the governmental pecking order that seizes the critic by positioning them on the margins of society, a place explicitly designated for the unconventional.

Undeniably, acts of silencing have made sure Sio's critique of culture stays subordinate to a dominant narrative that modern Tonga represents a Christian, peaceful, and prosperous nation impervious to dissent and discord from below. How then, has this affected his community work as a youth educator? Central to his social activism is teaching practical skills in wood and bone carving and sculpturing to teenage boys who have dropped out of high school in his home village, Haveluloto. Contending with the onslaught of conservative culture and having to be self-reliant, having to create home-grown remedies for social problems inside his community, has made Sio more determined and resolute in his style of activism and criticism. On this point Sio's partner Serene Tay, herself a contemporary Maori artist, discussed how being a youth educator translated into social action.

Io [yes], there is certainly so much mahi [work] needed to be done in Tonga. Sio and I were talking about the social entrepreneurship, the social consciousness needed [for] foot soldiers who are representing the people for the people. More importantly it's about creating a democratic voice from the youth we are engaged with that makes art $s$ powerful in my opinion. We are able to go into depths of the truth/realities, the centrality of our culture/communities, and speak from a place of knowing because ultimately if we are going to heal as a people we will have to be honest and front up to the real issues. (Tay, 2013b). 
What are the "real issues" Tongans have "to be honest [about] and front up to?" "To heal as a people" means what concisely? (Tay, 2013b). The group of young males aged between 15 and 19 years old living in Sio's village whom he mentors through art were bound by circumstances outside their control. An inventory of youth development issues reflected not singly their everyday lives in Haveluloto, but that of many ethnic minority males from low economic households in urban, developed countries such as New Zealand, Australia, and the USA: Single mother household, absent father, high school drop-out, unemployment, poverty trap, younger siblings, stressed resources, crisis living environment, gravitation towards boys of similar backgrounds, alcoholism, physical violence, feelings of hopelessness, abandonment, and despair.

Putting Serene's sentiments in context, the list of domestic troubles were "real issues" which ideally get addressed if villages constituting the nation accept that for increasing numbers of young people, this is Tonga straight up "honest" (Tay, 2013b). For Haveluloto, a village of 3,465 people on Nuku'alofa's outskirts where 359 were aged between 15 to 19 years old, what were the employment prospects of the young males whom Sio guided on a voluntary basis? (Statistics Department Tonga, 2013). His work was unpaid, not that he ever raised this as an issue, but the fact is the costs involved in teaching young males practical art were met by his household income.

Where was the army of aid donors from Australia, New Zealand, China and Japan that had set-up offices in Tonga to rival for economic and political stakes in this small island developing state? To be blunt, there was no interest in assisting village programmes for youth education and employment. Sio's work catered to the most vulnerable, 
uneducable, unwanted sector of Tongan society - teenage male drop-outs, sons of solo mothers - mothers like me who were sole care-givers for their adolescent sons and whose sons made up the fastest growing national demographic. Where was Tonga's Ministry of Education and Training when it came to collaborating with their stakeholders at village level on youth development programmes, or at the very least, on developing art curricula for secondary and technical institute education? Lastly, where was the multitude of churches with their charity work for "the poor in spirit, those who mourn, the meek, the merciful, the pure in heart, those who are persecuted," and every downtrodden human kind listed in the Sermon on the Mount? (Holy Bible, 2011).

Would the real thinking people please stand up?

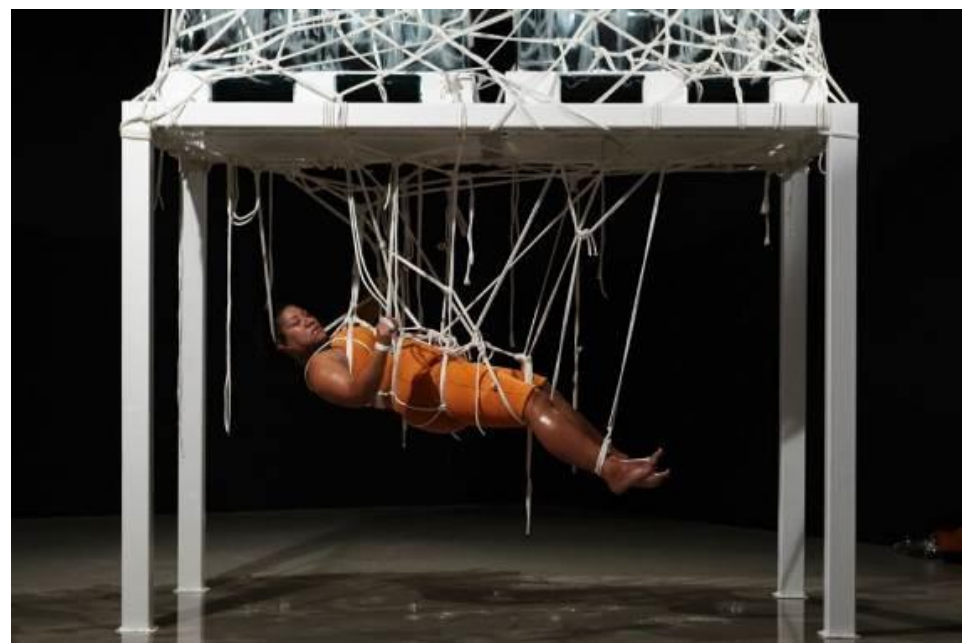

An installation about climate change in the Pacific Islands called "i-Land $x$-Isle" by Australian born performance artist Latai Taumoepeau of Nukunuku and Nuku'alofa in the Kingdom of Tonga. Photograph by Australia Network News. 
Who were the real "thinking people" in Tonga? (Zinn, 2003). The independent critic and strategies for social activism looked like who and what to grassroots, village roots, and outer island communities? Put it to the panel for a "thinking people" scorecard I thought, appealing to Sefita Hao'uli, Kalafi Moala, and Melino Maka to make sense of past critics, and for what purpose had today's people movements and spokespeople for social change adapted their causes to the present political situation. The following sections of this essay have strung together their reflections and recollections on how criticism and activism triggers change in contemporary Tongan society. Woven into the exchange of ideas are my musings and frame of inquiry as the author and a contributor to Tongan academia. Prompted by Sefita, Kalafi, and Melino's dialogue, I reconsider here what my role is as a university knowledge-broker.

Any measure of reliability in my research on Tonga is tied to ethical obligation. I am duty-bound to turn a razor-sharp tool of critical self-reflection on the writing I produce to assess whether my work is relevant, accurate, fair-minded, and useful to the people and place I publish about. I am an insider of Tonga. If this amounts to specific principles, then it is researcher competency and integrity. I have to perceptively plan what I am doing and the rationale validating my action. Moreover I have to be truthful, especially under political conditions when truth-telling is restricted. Despite my tenuous location inside Tonga because of my half-cast roots in which I am "halved and carved" as the inheritor of European colonial ancestry, I do claim Tonga as my origin homeland (Marsh, 2009). I am not saying I occupy the same insider position as critics, commentators, and activists who identify as full-blooded Tongan. This category does not fit me.

My mother raised me half-cast which is her social box in Tonga not full-blooded, and I have no desire to appropriate 
another's identity type but my own, the one my mother gave me and expected I wear properly to maintain the family character. I can only imagine the pressure to conform to cultural conservatism would be heavier, generating graver political fall-out and social cost for full-blooded Tongans, which is why I have immeasurable respect for Visesio Siasau's artwork and activism as a youth educator in Haveluloto. The selected discussion featured here ought not to be read as a conclusive and complete text, but rather, as a sequence of insights and commentaries outlining Tongan accounts of how human agency instigates change.

Kalafi Moala: I remember asking a Chinese friend of mine many years ago in San Francisco how I can tell a restaurant with authentic Chinese food as opposed to one that caters to non-Chinese. He answered: "You look inside the restaurant and you will find out. If there are mostly Chinese people eating there, it's authentic. If you see mostly white tourists dining, then you know they've altered the foot to fit the taste of Westerners." That's a wisdom I've used everywhere I've travelled and wished to choose a good Chinese restaurant. I recall this Teena, as you talk about favourite commentators for Radio New Zealand and Radio Australia. Some of our academics and commentators often "alter the content" of reality to match the palate of those they are serving. For too long many of our people who provide commentary on Tonga's behalf have catered "unfaithfully" to the tastes and demands of the colonial mentalities. (Moala, 2013a).

Teena Brown Pulu: Kalafi, what a clever friend to share advice that can be applied to more than just people's tastes for Chinese food-original or modified. I agree with you. To me, Tongan academia as a collective has a history of having the majority of commentators and writers offer a version of Tonga modified for Western tastes. It's the dominant brand of Tongan 
scholarship, and I purposely do not want to be part of this genre because I think if you're not writing for and speaking to your own people, you've lost the plot and will surely end up regurgitating the same old storyline. It is simply getting worn down and unbelievable (almost like a fairy-tale) to still read writers and hear commentators spinning the official New Zealand government line that the Tongans are oppressed by their own rulers, but New Zealand will save the poor Natives from the Chinese takeover of the Pacific Islands. Then the New Zealand government will crown 'Akilisi Pohiva (the 73 year old male politician) the king of the Tongan people, and the Natives will learn that Western democracy, Western allies, and Western puppeted leaders that New Zealand appoints for us because New Zealand can control is the best system of colonialism in the world. Amen and A[wo]men, although New Zealand does not endorse Tongan women for political leadership. Only 'Akilisi Pohiva because he is a 73 year old Tongan man. The New Zealand government and parliament have the cheek to lecture the Natives of the Pacific Islands about gender equity in their parliaments. Perhaps they naively think the Natives don't understand political and moral double-standards when they see it. (Brown Pulu, 2013c).

Tackling the "thinking people" scorecard, Kalafi Moala evaluated the overall performance and presentation style of public remarks about Tonga delivered by Tongans to Radio New Zealand and Radio Australia (Zinn, 2003). Twenty four years as an independent media operator gave Kalafi the knowhow to put hegemony under close examination. Gramsci's hegemony in this context is taken to mean the systematic control of talk on Tonga by "Tongan academics and commentators" for media use and public dissemination (Moala, 2013a; Gramsci, 1971).

Honing in on the media operator and target audience's persuasiveness in shaping the content and delivery of what the 
speaker transmits over public airwaves, he questioned the reliability of a pre-programmed storyline. Kalafi meant there appeared to be meagre thought about how editing the script to suit audience tastes did more to concretise dated views on Tonga than critique the dominant discourse of Western-driven media. What was the game plan of Radio New Zealand and Radio Australia's coverage of Pacific Island states? To report actuality; to find out about real life as it happens and in the process of learning, raise awareness about people with less, people without power? Or was it more to do with presenting a story; creating an image of islanders on atolls and their affairs and dramas which the audience could grasp because it was the voiceover repeatedly drummed into them? (McLuhan, 2001).

Interrogating loyalty and dependability, Kalafi also suggested that a Tongan speaker who accommodates the audience's palate while knowing that a derisive tale of an antiquated Tongan hierarchy is anticipated, gets charged a social cost. At once, the commentator is penalised by his own people if Tongans see the observations worded on their behalf "have catered unfaithfully to the demands of" an outside colonising force. For Tongan academics truly wanting to perform "the job of thinking people," trustworthiness was indispensable. Imperative to thinking was proficiency in analysing the complex political conditions under which Tonga was expected to work as a fledgling democracy, instead of telling tales to sceptics and cynics living in New Zealand and Australia.

Keeping with the subject of social commentary, Sefita Hao'uli saw artists as boundary crossers. The artist performed the role of "crossing" by firstly entering "taboo territories" and secondly, by being an intersection, a crossroad, for separate traditions and their ideas to coalesce (Hao'uli, 2013a; Taylor, 2013). A radio and television broadcaster with over thirty 
years' experience in New Zealand media, he understood the arts and media in Tonga as industries anchored in communication.

Concisely he stated that integral to the media broadcaster was the mode and manner in which hard-to-ask questions and social conflict were managed in the public domain. As a truthteller, the Tongan broadcaster had the difficult task of firstly dealing with their own "internal conflict" - the split in loyalty between culture and criticism - so that friction and fracture did not swell up and get infected, disrupting the work flow (Hao'uli, 2013a). With a similar background to Kalafi, Sefita also queried the Tongan media's purpose as the fourth estate of a novice democracy.

Urging Tongan media to deliver clued-up communication, he intimated around the quality of public programming. Media quality in Sefita's text alludes to communication free of self-censorship, which obstructs a broadcaster from transmitting critical thought and speech through public airwaves and printed press (Hao'uli, 2013). What is "the job of thinking people" in Tonga? (Zinn, 2003). He noted a cornerstone could be the individual leadership of broadcasters who were not afraid "t0 put it on the line" (Hao'uli, 2013a).

Sefita Hao'uli: Artists of course are crossing boundaries: That is their work. I think if you are a Tongan artist then you need to live overseas, experience working and living overseas to enjoy your work and to grow in your work. In Tonga, art has been stifled and neglected.

Teena Brown Pulu: I agree with you about the arts and literature in Tonga. You're part of this community too Sef as a writer. But I don't think you would have written your best work in Tonga; you'd get put in jail. Tongan mentality: Jail people who think for themselves.

Sefita Hao'uli: I'm always in jail; I live in jail, incarcerated. The media in Tonga need to seek out people who 
are courageous enough to put it on the line; that is, asking the questions that need to be asked while confronting internal conflict knowing that this is where the structural tension lies.

Melino Maka took a different route to Kalafi Moala and Sefita Hao'uli to arrive at what he considered to be "the job of thinking people" (Zinn, 2013). He had made agricultural trade his contributing field to Tonga's economic development, a local primary industry couched in a global recession declining, diminishing, and struggling for air without adequate life support from any such "national plan" (Maka, 2013). Melino sidestepped my asking if village farmers' cooperatives were the people movement in Tonga triggering change to the country's dismal trade record.

Focusing his discussion on national politics he spoke of a "leadership crisis." Tonga, he thought, was deprived of leaders who prioritised agricultural trade as vital national income (Hayes, Scheufele, Huge, 2006). Failure to mobilise the farming industry had incapacitated what was left of the country's earning potential (Maka, 2013). For Melino, political leadership that could steer the country into work and away from China's receivership as the bank lender with whom the Tongan government had unpaid loans collecting interest, summed up thinking people.

Teena Brown Pulu: Melino, what about village roots farmers like the Eastern district farmers' association, is this a people movement in Tonga?

Melino Maka: With the present government, there's no clear national plan for the farmers to produce and the market to provide a sustainable income. The government is distracted with internal politics. When the new government came in [in 2010] they went about undermining the previous government's work, taking Tonga backwards. Usually when a new government takes office they continue with the previous government's work but change the policy around how that work 
meets the economic goals in the national plan. The biggest issue facing Tonga is leadership; we have a political leadership crisis. But if we can gather leaders who have a plan, a vision of how Tonga will develop, what it will be like in 5, 10, 20 years' time then that's a start. A national plan for Tonga has to be based on economic development and getting people into work, bringing in an income for the country, not relying on aid donors and begging your way to prosperity. The farmers are important to Tonga because our baseline economy is farming and it's work that everyone can do. Not like professional sport where it's not a job, a form of income that all Tongans can do for a living.

Teena Brown Pulu: What about people movements in politics? What does that look like in Tonga at present?

Melino Maka:

Last night I went to 'Akilisi Pohiva's public meeting for Tongan supporters of his Democratic Party at Onehunga Bowling Club here in Auckland. About 20 people showed up; that's being generous, it was probably less, the die-hard supporters from back when the pro-democracy movement was starting up in the late 80s, 90s. I was disappointed that there was no economic development platform to launch new policies; same old politics we're used to seeing from 'Akilisi. He said he's not worried about the economics of running the country. He's worried about getting the right government.

Teena Brown Pulu: He's worried about getting into government is what he means.

Melino Maka: The economy has to be at the forefront of government, otherwise the political system is redundant. What does democracy mean if the people in the country can't make a living? He told his supporters the Democratic Party can only get support to form a government from the 5 independent people's representatives but not the nobles, and that's why they want to change the electoral system to stop the nobles forming a government. His supporters were saying the media is not 
balanced because Kale'a [newspaper] reported that there's a split in the party leadership between 'Akilisi [Pohiva] and Sitiveni [Halapua]. 'Akilisi played it down and said he no longer has a say in the Kale'a.

Melino paired off democracy and economy hand-in-hand. Systematically, he saw the two as inextricably linked in the way that democracy failed to deliver civil freedom and consumer choice if the state did not create jobs to raise household incomes above subsistence living. Criticising both the government led by the noble Prime Minister Lord Tu'ivakano and the opposition headed by 'Akilisi Pohiva with the same judgement, their deprioritising of economic development through primary trade dashed his expectations of the calibre of political leadership required to move Tonga out of financial depression.

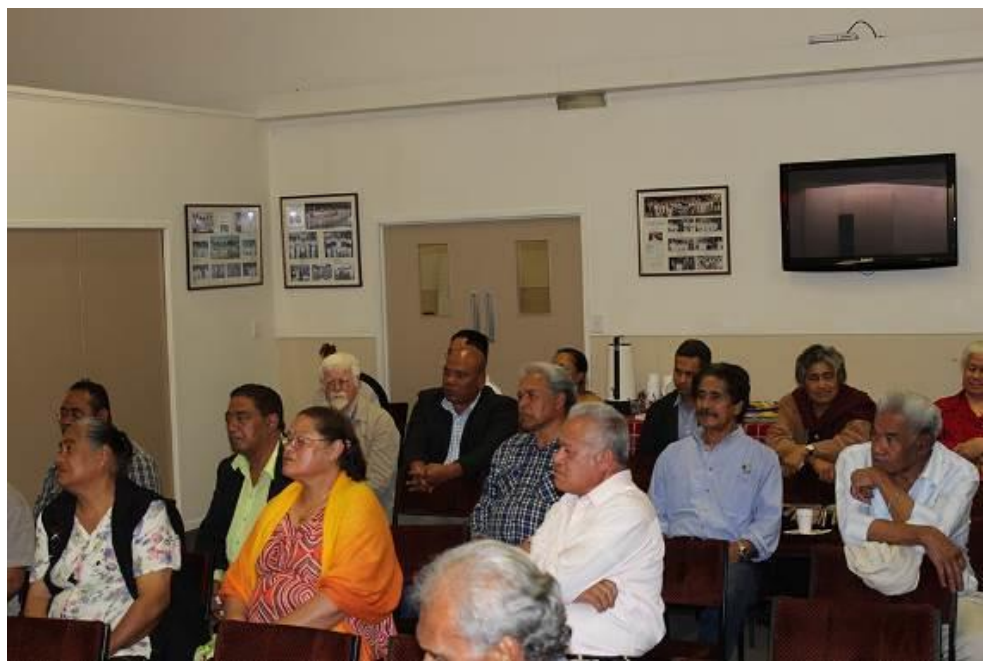

Melino Maka (second from left at the back) seated next to long-standing New Zealand parliamentary reporter Anthony Haas at 'Akilisi Pohiva's public meeting in Onehunga on 2 December 2013. Pohiva's meeting updated Auckland Tongan supporters of his Democratic 


\section{Party of the Friendly Islands on party politics in Tonga. Photograph by Kalino Lopeti.}

A noteworthy inquiry surfaced from Melino's discussion: Did Tongan voters have a range of political options in the upcoming 2014 general election? Given the dearth of leadership in national politics, was there a variety of candidates from the commoners for prime minister? Or was it likely that a different noble would be elected to the premiership in 2014 due to the lack of selection and limited political scope among the people's representatives?

\section{The job of thinking people}

His enduring legacy is the courage to say the most difficult things to the most difficult people in the most difficult circumstances.

\section{Robert Shetterly on Edward Said}

Closing this essay with the voices of two Tongan artists Latai Taumoepeau and Visesio Siasau, one Tongan woman and one Tongan man, one Australian born and located, and one born in Tonga and living in Tonga and New Zealand, is purposeful. I think they do "the job of thinking people" (Zinn, 2003). The job I do as an academic, by comparison, is skills based. Concisely it involves applying a skills-set to various problematic situations to gather information and answer a research inquiry.

The university system is increasingly bureaucratised and integrated into the machinery of government as a method of state control over the production and consumption of knowledge (Baudrillard, 1998). Consequently, there is little priority and funding given to thinking outside of a study's limits. There is definitely not enough thinking around how 
state hegemony has muted criticism and softened critics, deactivating them from speaking truth to power (Said, 2000). In actual fact, university academics represent the knowledge hierarchy; they replicate the establishment; and they behave as an authority. An academic career is locked into research outputs manufactured through publications. Go forth and multiply, a wisecrack on the biblical expression.

The individual discussions of Sefita Hao'uli, Kalafi Moala, and Melino Maka intersected on one point. Emphasising that leadership and courage drive a spokesperson to have a social conscience about how ideas are communicated, plans are envisaged, and problems are made sense of, underlies what thinkers do. Of course as Sefita made clear, this is not without "internal conflict" for Tongans (Hao'uli, 2013). Having courage to speak up under pressure from the establishment to tone it down, or edit the story to conform with the popular palate of what people want to hear is difficult, dangerous, and puts one at risk of getting forced out to the periphery.

In saying that, contemporary artists such as Latai Taumoepeau and Visesio Siasau are, in Futa Helu's sense of the term, a Tongan paradox (Helu, 1999). They are alienated for "crossing boundaries" (Hao'uli, 2013). They are marginalised for problematising convention as a system of power designed to control thinking from travelling beyond its rules and reprimands. Consciously, they alienate and marginalise themselves by transgressing borders and breaking through roadblocks with their work.

But in their vulnerability and openness to censure, disapproval, and disparagement they perform a function, a duty to society, where the burden of "internal conflict" prevents most from having a go (Hao'uli, 2013). What would Tonga be without the art, politics, and passion of thinking people? Where would Tongans be without artists and writers remaking the past to relate an insider's story, the alternative 
history of how we got like this, and why our lifetime will foretell the future? (Borofsky, 2000).

Latai Taumoepeau: I'm more interested in the invisible, intangible cultural stuff that's attached. This [ngatubark cloth] may have been a gift in a funeral setting because not only is this material culture used to wrap the dead, it's also presented in exchange to show respect to the family that are mourning. It's used as a floor covering. There are different hierarchical roles that an object like this [ngatu] can play in a ceremony or a ritual that we don't see. And that's what we don't see when I open up this draw, I don't see that. I don't know that. But that's what I'm interested in. It's where this [ngatu - bark cloth] has been; what it's function could be; and how it still exists today.

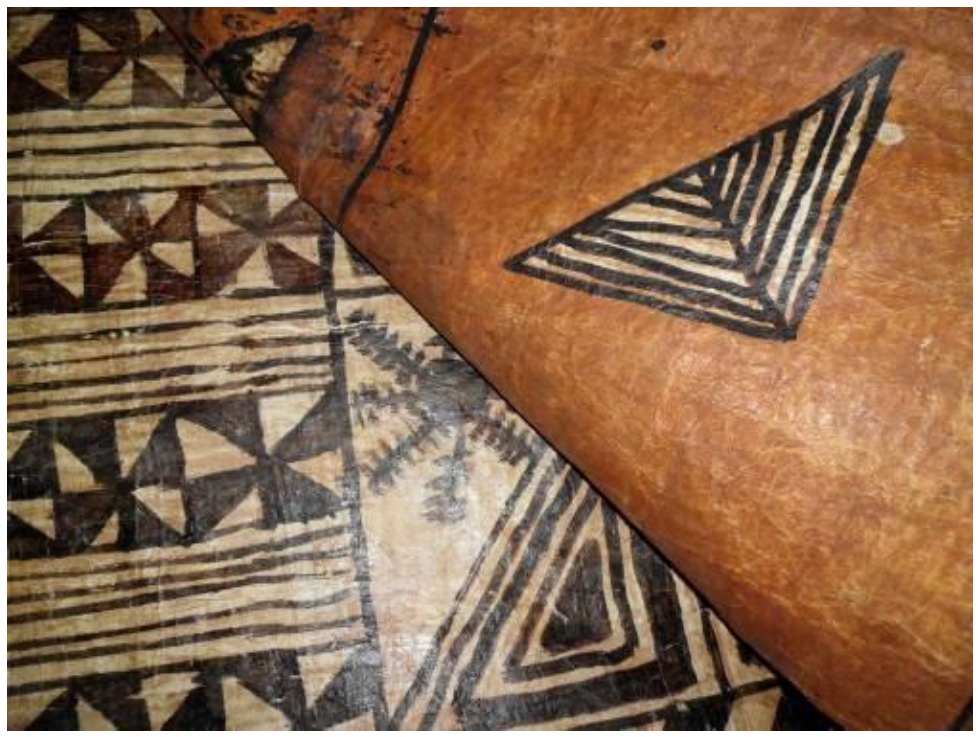

Ngatu (bark cloth) which is used as a form of traditional Tongan wealth in life cycle rituals such as funerals, in particular for ceremonial exchanges of giftgiving. 
One of our roles [as artists], it could be to preserve certain traditions. [To] recreate and maintain - not necessarily just the techniques of [making] the object - but the belief systems, the intangible things that go with it. There could be confrontation around some of those things because of varying spiritual beliefs and also the need to maintain a new lifestyle which is the one of the West, which is where we mainly live now. But I think artists have a perspective that may assist in keeping some of these things. And not just maintaining them as how they were always made, but ensuring that they evolve as well because that's part of the culture. (Taumoepeau, 2013).

Visesio Siasau: Yes, it is a critical constructive critique, as I am practising our knowing from the inside out, even though I realise that I am/we are vulnerable and isolated in the Vaka [vessel] that I am embarking upon, it is my responsibility as a Tufunga'i [artist/expert] to take on these challenges. My solace is sourced from inextricably knowing that our 'Otua mo'ui [living God] is always there to direct and guide us.

As a Tongan Tufunga'i [artist/expert] as I class myself, I have the responsibility to analyse, de-construct, reconstruct the intellectual dialogue from our Tongan cultural heritage, as well as be fully alert and ready to challenge the foreign values imposed [on] our politics, economy, religion and so on. Being present to reality also awakens our past, so that we are able to bring out the true essence of our knowledge. We will no longer allow the outsider, the foreigner researchers to [supposedly] "educate" or "make aware" within our people. [They] are also neo-colonisers telling us how, why, who we are, and what we know as Tongans. (Siasau, 2013).

\section{Afterword: The job of the critic}

The greatest threat to freedom is the absence of criticism.

Wole Soyinka 
Late evening of Saturday December 7th 2013 Kalafi Moala emailed from his home in Kolomotu'a, a town suburb of Nuku'alofa. Contemplating the essay draft I sent him, Sefita Hao'uli, and Melino Maka to comment on he wrote down some thoughts. Woven into his discussion was nostalgic and moralistic attachment to the kind of Tongan culture he knew and understood. Somewhat essentialist thinking, he thought of "harmony" as a conductor synchronising Tongans to sing in "unity" despite differences, disjuncture, and disagreement (Moala, 2013b). Inclined towards sociological structure, Kalafi conveyed a brand of criticism predominant among Tongan men of his age group, generation, and senior position in a hierarchical and patriarchal society.

Responding to the research inquiry - what is the job of thinking people in Tonga? - Kalafi offered a more complex set of questions to ponder. Can any given society function in the absence of structure and order organised and carried out by a group in power? In reacting against power, is confrontation and conflict the only strategy to shift the centre from the margins? And in reconfiguring "the centre of thinking," do the fringe dwellers become the new centre with all its clout, weight, and privilege? (Moala, 2013b). In Tonga's case, when social action deliberately crosses religious and cultural taboos knowing the mode of mobilising is an "act of declaring war" on the status quo, does such action reproduce "intimidation, defiance, or at its worst, violence?” (Moala, 2013b).

Whether I agreed with the logic by which he angled his argument or not is beside the point. Kalafi was doing the job of the critic of which he was as a leading journalist in Tonga. Begging to differ, he put his frame of questioning directly to me, the author and teller of this tale and a younger woman from an overseas generation of writers institutionalised by working in developed country democracies and Western 
universities. By doing so, he demonstrated that criticism might not automatically seek to disarm an opponent's stand, but instead, can endeavour to coax and sway the other to look closely through an alternative lens.

Frankly, I did not see eye-to-eye with Kalafi's judgement. Indicative of my different location in being a half-cast Tongan woman from a younger generation born and raised in New Zealand, I thought his dialogue was couched in a dated theory on culture and society. By my reading, he presented a critique that quelled the coercive force by which power turns human beings into nameless, faceless, featureless subordinates of a system, a type of nationalism, or as he worded it, the subjects of "Tongan-ness [which are the] factors that define our" being Tongan (Moala, 2013b). Who defines and confines "Tonganness?" Plainly not the people from below, those lowly ranked in a class structure designed to contain and rule over them.

Structuralism by design and intent, Kalafi's discussion evoked the twentieth century anthropology of Claude LeviStrauss based on fieldwork in the Amazonian rainforest (Levi Strauss, 1966). Here, Levi-Strauss contended that all human societies are founded on a system, a social and cultural structure, and that underpinning the way people organise themselves whether looking at complex metropolitan societies or simple non-industrialised societies was a meta-structure governed by taboos, proscriptions, and prescriptions (Johnson, 2003). In the modern era taboos were personified in group rules, boundaries, and retributions. As a heuristic practice, meaning a common sense approach to learning about society and the system of culture it is hinged on, structuralism proposed that "all phenomena in cultural worlds might be interrelated" (Stasch, 2006, p. 167).

This epitomised Kalafi's line of reasoning which stood at odds with the rationale I took up as a poststructuralist critic. Contrastingly post-structuralism, the school of thought I 
practiced, drew much of its theorising from 20th century French philosophers Michel Foucault and Jacques Derrida (Boyne, 1990). Not to be taken as Western thought that came after Levi-Strauss and structuralism, a poststructuralist critique sets out to interrogate well-established ideas about historical continuity and sociological structure. Put simply it is the study of rupture, discontinuity, and disjointedness in society and history. Situated around systematic cracks, fissures, and fractures it disrupts the romanticism of national unity and unbroken history, such as Tonga's fixation with a constant succession of ancient and modern rulers to give nationalism a sense of "tradition" and "permanence," to paraphrase the late Futa Helu (Young, 1990; Janman, 2012).

Roy Boyne's book, Foucault and Derrida: The Other Side of Reason, captured how post-structuralism had reorganised Western thought "in the last years of the [20th] century" (Boyne, 1990, p. 1).

It tries to find something out about the kind of society which is taking place in the last years of the century. No doubt the empirical sociologist will be aghast to find that, instead of an examination of structural change ... the solid core of investigation concerns the nature of madness, the birth of the prisons, problems of textual interpretation, the nature of the self in ancient Greece, and forms of theorizing current within socialist, feminist and anti-racialist movements. (Boyne, 1990, p. 1).

Motivating a poststructuralist critique is the relationship between power, knowledge, and language. A critic of this genre undresses how those in power define knowledge about the subject, and by controlling the language in which information is communicated in the public domain subjugate 
people and prohibit knowledge from below being counted as valid, authentic, real, factual, or even believable.

I say this as a half-cast Tongan writer who through my work puts up with hostility and argumentativeness from Tongans whose cultural priority is to identify solely as Tongan, and by insisting on their theory of "Tongan-ness" dismiss my half-cast identity for not being "adequate enough to stand on" (Moala, 2013b). This is a standard pattern of cultural behaviour forced on me I have come to accept and resist concurrently. Performances of this kind have shown that the actors only know the lines they have learned, memorised, and rehearsed, and deliberately do not own up to not knowing any other script because theirs is the one play on "Tongan-ness" that matters (Moala, 2013b).

The influence I have to effect change is to write. Therefore, I write to speak back to the centre. I write to discomfort smugness. I write to uncover what does not get talked about openly because it is too painfully true to discuss in objective, value-free, nondescript, flavourless language. Most of all, as Nelson Mandela put it, I write to understand a nation - that being Tonga the homeland state and its overseas diaspora where the only way I can know the people and place is to study how Tongans treat their "lowest citizens."

It is said that no one truly knows a nation until one has been inside its jails. A nation should not be judged by how it treats its highest citizens, but its lowest ones.

\section{Nelson Mandela}

My purpose for writing an afterword that precedes Kalafi Moala's impressions about the sharpened points raised in this essay is two-fold. Firstly, I want the collection of four essays on Dialogues with Sefita Hao'uli, Kalafi Moala, and Melino Maka to be read critically not casually. Subjectivity and 
identity shape my relationship as the author to the subject under examination, and the way in which I see myself reflected or refracted in the subject. I am therefore a value-laden actor in the narrative related to the audience whose thinking is informed by the subject and sculpted by the school of thought I write from and the literature I read. Textually, readers should be mindfully aware that the literature a writer gravitates to is internalised in their thinking and reproduced in their writing, expressly in how a writer frames an inquiry and constructs an argument.

In writing criticism of development reports published by the Tongan government, regional inter-government organisations, aid donors, consultants, and international banks, I have concentrated on a systematic flaw of bureaucratic practice. Succinctly, this body of printed material comes across insubstantial and ineffectual in eliciting change because it is rootless and ahistorical. The authors of these reports intentionally conceal from the reader's view the origin source which manufactures their thinking. Where in world history are these development models traced to and copied from? "In short, you will never know" to quote Derrida because the bureaucracy's library of development reports will never tell you (Derrida, 1998). And if the general public does not know it is unlikely they will criticise, which drives the state logic of not making it known from where development concepts and designs originate.

Secondly and knitted to my first point, in reading the essay collection with Sefita Hao'uli, Kalafi Moala, and Melino Maka, it is perceptible that we diverge in opinion on a number of development dilemmas facing Tonga the homeland state in relation to the overseas diaspora of Tongans living in New Zealand, Australia, and the USA. We are human products of our own lived experience affected by the generational and gender locations and dislocations we contend with and make 
sense of in our development work. But despite our differences we are collective sense making, considering each other's ideas and distinctiveness from our own for the purpose of dialoguing and documenting the conversation exchanges. The fact that we carefully listen and read the views of others we might not comfortably align with is a testimony to our individual loyalties to Tonga, to collaboration with Tongan people, and to contributing the best we have to give to development, however we critique and practice those working principles.

Kalafi Moala I wish we had another meeting where some of these things could be discussed more, but I think it is sufficient discussion, and I do appreciate the clarity of your writing Teena, with the inputs made. (Moala, 2013b).

Sefita Hao'uli Good to see Kalafi raising relevant questions - some of which cannot be fully answered without further discussions. And many I'm trying to take in because they're challenging. (Hao'uli, 2013b).

Teena Brown Pulu Thanks Sef, agree with you that the questions Kalafi raised are so relevant and challenging. It is essay four really. We could talk all day about this discussion piece and still have more to talk about. (Brown Pulu, 2013d).

\section{The last word}

Kalafi Moala: Is peace the absence of conflicts and tensions? Or is peace the existence of purposeful loving relationships in the presence of contradictions, conflicts, and tensions? Harmony is not when things are no longer in conflict or in tension. Harmony is like unity. It is not uniformity, but it's like an orchestra with all the different instruments playing different notes, and giving beautiful music. If these different instruments each play the same note sounding exactly the same, it would not be music. It would just be a deafening loud noise, offensive to the hearing. Unity is only real when it is a unity in diversity. I suggest that resolving conflicts and tensions 
is not getting rid of them but living life purposefully in the midst of them.

I appreciate the identity base upon which you view things Teena, e.g. being a half-caste Tongan. But as much as this a reality to our brothers and sisters who are of mixed blood, I do not think that this base of identity is deep and adequate enough to stand on. I have never seen being Tongan as defined by whether we are full blood or half-caste, or by our place of birth (Tonga or overseas). I do have Fijian blood; my wife's grandmother is Samoan/German; and her grandfather is Uvean. Crazy and mixed up, yeah? There are many other factors that define our Tongan-ness.

We do not determine the centre or the margin by our identity. Is not the centre a social reality that is always shifting? The centre of today may be the margin of tomorrow, and may not even exist within the circle of our consciousness and experience beyond tomorrow. If there are shifting centres, then there are shifting margins. Over several decades, I have seen the centre where we are comfortable to view things from within Tonga shift a few times. The only thing we can be sure of is the shift happens.

Crossing borders and boundaries in social activism: My question is who/what creates these borders/boundaries? They may be social, religious, cultural, and maybe even economic. Are they real or imaginary or a mixture of both? But are they borders/boundaries we need to cross or are they social dividing lines that simply tell who is in the inside and who is on the outside; who is left and who is right; what is important and what is not? And then, how do we tell which side is inside and which side is outside? More definitions, yeah?

On art creations - some of the so-called boundaries we are trying to cross have already been crossed before. Why are boundaries we create or identify so often religious, or moral restrictions and standards, or socio-cultural? Should there also 
be economic boundaries we are trying to cross? And does economic activism mean we become anti-religious or antisocietal? Is it because we have created a moral centre for ourselves, and operate from that centre outwards? But maybe the activists of tomorrow will dispute our centre and introduce or create their own centre. There are shifting centres and shifting borders/boundaries from generation to generation, and one set of lived realities to another.

Nothing new in the so-called creative art of socio-religious activism. Activism must have in its very nature the purpose and ambition to offer creative options to the way people live their lives. Crossing the boundaries in this case is simply just an act of intimidation or even defiance, declaring war on the centre of thinking [and] offering a new centre as the place to build and establish one's thinking and life from. It is hegemonic at best and violent at worst, if we wish to judge it from our current centre of consideration.

Is justice the absence of injustice? Are there any restrictions to freedom? What is freedom anyway? If freedom is the ability to create our own moral centre by deconstructing the social structures that infringe on our freedom to do anything and everything we like, [then what are the consequences of our freedom infringing] on the freedom and rights of others? We may be trying to create a new centre that everyone operates from, but is this really democracy or the worst form of demagoguery?

Is our activism an act of individual, independent anarchy, or can we use human communication skills to persuade others to come with us in the same direction, but not necessarily in the same way? [Lastly] the right of the indigenous: The perception is [that] indigenous is right, [that being] indigenous gods, indigenous values, indigenous laws, indigenous practices. I would challenge any assumption that things indigenous are the best and the knowledge of such gives us authenticity. Maybe 
this is a subject we can discuss for later [publications]. (Moala, 2013b).

\section{The end note on hafe-kasi}

Sefita Hao'uli: Afakasi in Samoan is hafe-kasi in Tongan and both are transliterations borrowed for convenience, rather than for the meaning that it would convey in the Tongan lexicon. Tongan usage gave this term meaning, and it could be used endearingly or disparagingly. It was originally a word without Tongan meaning, whereas I sense that you [Teena] usually see or view it as a word to signal exclusion, non-inclusiveness or separateness.

When Tongans express family connectedness with others of [a] different ethnicity or "blood," it is much more inclusive and embracing because it automatically speaks of one being Tongan and "part of" as opposed to the aloofness of "half" and the foreign concept of "caste." Commonly used it translates as thus: "We have a German part," which is quite different from saying we are part-German. The speaker never says he/she is Tongan. Built into the sentence is the given that he/she is Tongan, and [from there] the speaker continues to identify the other parts of his/her being, but never by how much. There are no halves or quarters when Tongans refer to "part." It is enough that they are part and the fractions are considered inconsequential.

A reference to a different ethnicity within the family automatically acknowledges that they are Tongan with "parts" or konga from another ethnicity. When expressed in this way, it is usually done with pride, inclusiveness and without shame or blame. The meaning that is given to hafe-kasi depends a great deal on how you view yourself. If you view yourself as Tongan with parts from other sources it will come across as that - even if you cannot speak the language. I understand the angst of those who have identity issues because all of my children are in 
that space. As you yourself admit [Teena], the definition of afakasi is transient, but I say it should be transitory. (Hao'uli, 2013c).

Kalafi Moala: Thank you Teena for the additions, and Sef for your commentary on hafekasi. I fully agree with what you have shared. And I think it is a very important statement you have made Sef, not just for our Tongan side of things, but there are Hawaiians, Maori, Samoan, Fijians, in fact throughout Pasifika [who] deal with the same type of identity issues. (Moala, 2013c).

\section{On a final note}

Sefita Hao'uli's annotation on how the transliteration of half-cast into hafe-kasi shifts in meaning as it crosses over from colonial English to Tongan idiom revealed difference. There were glaring distinctions between how the original term was intended to specify the off-spring of English gentlemen in the colonies and Native women, and its vernacular, hafe-kasi, which signified another ethnicity present other than Tongan. If to describe "family connectedness with others of [a] different ethnicity" was one of the ways the half-cast label borrowed from English had been interpreted, then the Tongan social landscape looked richer for it in my eyes (Hao'uli, 2013c).

By Sefita's description, the Tongan ethnicity generally remained fixed as the centre with the other part attached on the side, which made me question why full-blooded Tongan relatives, including my father, treated me like the trophy child because they associated my braininess, self-confidence, forthrightness, well-written English, and slim body size with my Palangi (white/European) maternal grandfather, Stanley Brown. When I scan the contents of my life, being the favourite grandchild of my half-cast mother's nuclear family as well as indulged and privileged over the full-blooded Tongan grandchildren from my father's village Kolonga because I am 
half-cast, I wondered why both sides always conceptualised the personality traits they admired about me as Palangi not Tongan?

It irked me that the only Tongan trait people repeatedly said I possessed was a fakapo'uli temperament I inherited from my maternal grandmother's kinfolk, the Kaho family; the people to whom the Prime Minister Lord Tu'ivakano belonged and headed as their noble. As my prim and proper half-cast mother recalled of her Tongan mother's family in the one interview I recorded of her for my PhD thesis: "The Kaho family are not fakapo'uli. They are just not ass kissers like other Tongans." (Brown Pulu, 2007). I see sense in my mother's exclamation. How could I not approve of half-cast indignation from the woman who raised me to be me?

Kalafi Moala concurred with Sefita's explanation of how Tongans applied hafe-kasi in speech references and on that note, we ended this third essay in a series of four with some loose agreement that identity is transient, if not transitory, like the people who wear it. 


\section{References}

Anderson, B. (1991). Imagined Communities: Reflections on the Origins and Spread of Nationalism. London and New York: Verso, Revised Edition.

Borofsky, R. (Ed.) (2000). Remembrance of Pacific Pasts: An Invitation to Remake History. Honolulu, Hawai'i: University of Hawai'i Press.

Boyne, R. (1990). Foucault and Derrida: The Other Side of Reason. London, United Kingdom: Routledge.

Brown Pulu, T. (2013a). Rethinking Development in Tonga: Dialogues with Sefita Hao'uli, Kalafi Moala, and Melino Maka. Te Kaharoa: The e-Journal on Indigenous Pacific Issues, 6 (1): 306-344.

Brown Pulu, T. (2013b). Modern Colonialism: Dialogues with Sefita Hao'uli, Kalafi Moala, and Melino Maka. Te Kaharoa: The eJournal on Indigenous Pacific Issues, 6 (1): 345- 383.

Brown Pulu, T. (2013c). Email correspondence to Sefita Hao'uli, Kalafi Moala, and Melino Maka. Auckland, New Zealand, December 2.

Brown Pulu, T. (2013d). Email correspondence to Sefita Hao'uli, Kalafi Moala, and Melino Maka. Auckland, New Zealand, December 8.

Brown Pulu, T. (2007). Kakai Tonga ‘i 'Okalani Nu'u Sila: Tongan Generations in Auckland New Zealand. Unpublished Doctor of Philosophy Thesis in Anthropology, University of Waikato, Hamilton, New Zealand.

Boyer, D. (2003). Censorship as a Vocation: The Institutions, Practices, and Cultural Logic of Media Control in the German Democratic Republic. Comparative Studies in Society and History, 45 (3): 511-545.

Brown Pulu, T. (2013b). Modern Colonialism: Dialogues with Sefita Hao'uli, Kalafi Moala, and Melino Maka. Te Kaharoa: The eJournal on Indigenous Pacific Issues, 6 (1): 345- 383.

Brown Pulu, T. (2013c). Email correspondence to Sefita Hao'uli, Kalafi Moala, and Melino Maka. Auckland, New Zealand, December 2. 
Baudrillard, J. (1998). The Consumer Society: Myths and Structures. Thousand Oaks, California: Sage Publications.

Derrida, J. (1999). Forgiving the Unforgivable: Public Lecture. Auckland Town Hall, Auckland, New Zealand, August 18.

Foucault, M. (1970). The Order of Things: An Archaeology of the Human Sciences. New York, USA: Vintage Books, A Division of Random House Incorporated.

Foucault, M. (1972). The Archaeology of Knowledge and the Discourse on Language, translated from the French by A. M. Sheridan Smith. New York, USA: Pantheon Books, Tavistock Publications.

Foucault, M. (1980a). Power/Knowledge: Selected Interviews and Other Writings 1972 - 1977. New York, USA: Pantheon Books.

Foucault, M. (1980b). The Will to Truth. London and New York: Tavistock Publications.

Gramsci, A. (1971). Selections from the Prison Notebooks of Antonio Gramsci. New York, USA: International Publishers.

Hearn, J. (2006). Rethinking Nationalism: A Critical Introduction. London, United Kingdom: Palgrave MacMillan.

Hao'uli, S. (2013a). Discussion between Sefita Hao'uli and Teena Brown Pulu, Auckland, New Zealand, December 3.

Hao'uli, S. (2013b). Email correspondence to Teena Brown Pulu, Kalafi Moala, and Melino Maka. Auckland, New Zealand, December 8.

Hao'uli, S. (2013c). Email correspondence to Teena Brown Pulu, Kalafi Moala, and Melino Maka. Auckland, New Zealand, December 9.

Hayes, A., Scheufele, D. and Huge, M. (2006). Non-Participation as Self-Censorship: Publicly Observable Political Activity in a Polarized Opinion Climate. Political Behaviour, 28 (3): 259-283.

Helu, 'I. F. (1999). Critical Essays: Cultural Perspectives from the South Seas. Canberra, Australia: Australian National University Press. 
Hill, B. (2013). Tonga princesses to marry commoners. Australian Broadcasting Corporation: Radio Australia: Pacific Beat, Melbourne, Australia, August 7. Retrieved from

http://www.radioaustralia.net.au/international/radio/program/p acific-beat/tonga-princesses-to-marry-commoners / 1172706

Holy Bible. (2011). Matthew 5: Introduction to the Sermon on the Mount: The Beatitudes. Holy Bible: New International Version, Biblica Incorporated, Colorado Springs, USA. Retrieved from

http://biblehub.com/niv/matthew/5.htm

Janman, P. (2012). Tongan Ark. Auckland, New Zealand: An Independent Film by Paul Janman (70 minutes).

Johnson, C. (2003). Claude Levi-Strauss: The Formative Years. Cambridge, United Kingdom: Cambridge University Press.

Kelly, N. Et. A1. (Eds). (2005). Narrative, Memory and Everyday Life. Huddersfield, West Yorkshire, United Kingdom: University of Huddersfield Press.

Lemelle, S. and Kelley, R. (Eds.) (1994). Class, Culture and Imagining Nationalism in the Home African Diaspora. London, United Kingdom: Verso.

Lee, C. (1998). Press Self-Censorship and Political Transition in Hong Kong. The International Journal of Press/Politics, 3 (2): 55-73.

Levi Strauss, C. (1966). The Savage Mind. Illinois, USA: University of Chicago Press.

Lopeti, K. L. (2013). 'Akilisi Pohiva announced "Defender of Democracy Award 2013." New Zealand Kaniva Pacific, Auckland, New Zealand, October 24. Retrieved from

http://www.nzkanivapacific.co.nz/2013/10/akilisi-pohivaannounced-defender-of-democracy-award-2013/\#.UpbAPpWIrIU

Maka, M. (2013). Discussion between Melino Maka and Teena Brown Pulu, Auckland, New Zealand, December 3.

Mandela, N. (1995). Long Walk to Freedom. London, United Kingdom: Macdonald Purnell. 
Marsh, S. T. (2009). Fast Talking PI. Auckland, New Zealand: Auckland University Press.

Moala, K. (2013a). Email correspondence to Teena Brown Pulu, Sefita Hao'uli, and Melino Maka. Kolomotu'a, Tonga, December 1.

Moala, K. (2013b). Email correspondence to Teena Brown Pulu, Sefita Hao'uli, and Melino Maka. Kolomotu'a, Tonga, December 7.

Moala, K. (2013c). Email correspondence to Teena Brown Pulu, Sefita Hao'uli, and Melino Maka. Kolomotu'a, Tonga, December 9.

McLuhan, M. (2001). The Medium is the Massage: An Inventory of Effects. Berkeley, California, USA: Gingko Press.

McDonald, P. (2009). The Literature Police: Apartheid Censorship and Its Cultural Consequences. London, United Kingdom: Oxford University Press.

Medina, J. (2003). Identity Trouble: Disindentification and the Problem of Difference. Philosophy and Social Criticism, 29 (6): 655-680.

Mills, C. W. (2000). The Sociological Imagination: Fortieth Anniversary Edition, Afterword by T. Gitlin. New York, USA: Oxford University Press Incorporated.

Moala, K. (2013a). Email correspondence to Teena Brown Pulu, Sefita Hao'uli, and Melino Maka. Kolomotu'a, Tonga, December 1.

Neale, I. (2009). Tiny statues - big statement. Manukau Courier, Manukau City, New Zealand, August 21. Retrieved from

http://www.stuff.co.nz/auckland/local-news/manukaucourier/2774100/Tiny-statues-big-statement

O'Brien, K. (2008). Academic Language, Power, and the Impact of Western Knowledge Production on Indigenous Student Learning. The Australian Journal of Indigenous Education, 37 (1): 56-60.

Porta, D. and Diani, M. (2006). Social Movements: An Introduction. Malden, Massachusetts, United States: Blackwell Publishing, Second Edition. 
Said, E. (1978). Orientalism. London, United Kingdom: Routledge \& Kegan Paul.

Said, E. (2000). A View from Afar (Middle East) - An Interview with Edward Said. In Remembrance of Pacific Pasts: An Invitation to Remake History, edited by R. Borofsky. Honolulu, Hawai'i: University of Hawai'i Press, Pp. 443-452.

Sedghi, A. (2013). Red list 2013: threatened species across the regions of the world. The Guardian, London, United Kingdom, November 26. Retrieved from

http://www.theguardian.com/news/datablog/2013/nov/26/iucnred-list-threatened-species-by-country-statistics

Sheriff, R. E. (2000). Exposing Silence as Cultural Censorship: A Brazilian Case. American Anthropologist, 102 (1): 114-132.

Siasau, V. (2013). Email correspondence to Teena Brown Pulu, Hamilton, New Zealand, December 4.

Stasch, R. (2006). Structuralism in Anthropology. In Encyclopaedia of Language and Linguistics: Second Edition, edited by K. Brown. Philadelphia, USA: Elsevier Limited, Pp. 167-170.

Statistics Department Tonga. (2013). Tonga 2011 Census of Population and Housing: Volume 1: Basic Tables and Administrative Report. Government of Tonga, Nuku'alofa, Kingdom of Tonga.

Taumoepeau, L. (2013). Latai Taumoepeau interviewed for Body Pacifica: A collaboration between the Australian Museum, Casula Powerhouse Arts Centre, and contemporary Pacific artists, produced by Finton Mahony. Australian Museum, Sydney, Australia, April 17.

Tay, S. (2013a). Facebook post to Teena Brown Pulu. Hamilton, New Zealand, November 27.

Tay, S. (2013b). Facebook post to Teena Brown Pulu, Hamilton, New Zealand. November 30.

Taylor, G. (2013a). Afakasi Speaks: Poems by Grace Teuila Evelyn Taylor. Honolulu, Hawai'i: An Ala Press Offering, Pp. 23-24. 
Taylor, G. (2013b). The Power of Words: Grace Taylor at TEDx Auckland. TEDx Auckland, a TEDx Event of TED Talks, Auckland, New Zealand, August 3. Retrieved from

https://www.youtube.com/watch?v=LivPMiYik9g

Taylor, S. (2005). Identity Trouble and Place of Residence in Women's Life Narratives. In Narrative, Memory and Everyday Life, edited by N. Kelly, C. Horrocks, K. Milnes, B. Roberts, and D. Robinson. Huddersfield, West Yorkshire, United Kingdom: University of Huddersfield Press, Pp. 97-105.

Television Tonga News. (2013a). 'Ana Taufe'ulungake cited in Television Tonga News in English. Tonga Broadcasting Commission, Nuku'alofa, Tonga, October 23. Retrieved from

https: / / www.youtube.com/watch?v=7e7TeMTZNFk\&feature=c4overview\&list=UUJsR-wS1oz5i-OhNUsWU_9w

Young, R. (1990). White Mythologies: Writing History and the West. London and New York: Routledge.

Zinn, H. (2003). A People's History of the United States: 1492 Present. New York, USA: Harper Collins Publishers, Reprinted Edition.

\section{Glossary of Tongan, Samoan, and Maori terms}

Afakasi

Samoan transliteration of half-cast.

Fakapo'uli

Devilish tempered.

Hafe-kasi

Transliteration of half-cast.

Io

Yes.

Kiekie

A hand woven garment that women and adolescent girls wear around the waist.

Konga A reference to part, portion, piece or half.

Mahi

A New Zealand Maori term for work or to work.

Ngatu

Palangi

Bark cloth used mostly for ceremonial gift-giving.

Ta'ovala

A person/s of white/European descent.

Tufunga'i Artist, skilled craftsperson, an expert in the arts.

\section{Photographs}

Visesio Siasau and women of Haveluloto, Photography by Serene Tay, Tonga, 2013. 
Ancient god at the church podium, Photograph by Serene Tay, Tonga, 2013.

Jesus of the Sacred Heart, Photograph by Serene Tay, Tonga, 2013.

Ancient god on dialysis machine, Photograph by Serene Tay, Tonga, 2013.

Ngatu with hand painted figures by Visesio Siasau, Photograph by Serene Tay, Tonga, 2013.

'Akilisi Pohiva, Photograph by Melino Maka, Tonga, 2010.

Visesio Siasau and Teena Brown Pulu, Photograph by AUT South staff, New Zealand, 2013.

Miniature plastic sculptures by Visesio Siasau, Photograph by Imogen Neale, New Zealand, 2009.

Visesio Siasau and young boys from Haveluloto, Photograph by Serene Tay, Tonga, 2013.

Glass sculpture by Visesio Siasau, Photograph by Serene Tay, Auckland, New Zealand, 2012.

Visesio Siasau and young boys from Haveluloto, Photograph by Serene Tay, Tonga, 2013.

An installation by Latai Taumoepeau, Photograph by Australian Network News, Sydney, Australia, 30 September 2013.

'Akilisi Pohiva's meeting, Photograph by Kalino Lopeti, Auckland, New Zealand, December 5.

Ngatu, Photograph by Teena Brown Pulu, Auckland, New Zealand, 2 December 2013. 